\title{
INVENTING MARKET PROPERTY: THE LAND COURTS OF PAPUA NEW GUINEA
}

\author{
ROBERT D. COOTER
}

\begin{abstract}
This article reports field research on Papua New Guinea's land courts, which decide property disputes in customary law. Customary law did not contemplate exchange of real property outside the kin group. Changing conditions have created an irresistible pressure for markets in land, which require extending law to encompass exchange with outsiders. The freehold solution is to give absolute, unitary ownership over land to individuals and end the kin group's role in resource allocation. Alternatively, the kin group can be reconstituted as a cooperative with ownership rights. If imposed by legislative fiat, either of these solutions will disrupt the customary economy by displacing its incentive system. A better solution allows custom to evolve and modernize itself through the common law process.
\end{abstract}

Markets are so decisive to the character of modern society that their emergence from the world which preceded them exerts a continuing fascination over the mind. Questions about this opaque history also figure prominently in the grand ideological debates between capitalism and socialism, in which the function of property is explained by reference to its origins. In this article I explore the functions and origins of property by examining one of the few places on earth where markets in land have not arisenPapua New Guinea (PNG). Most land in PNG-over 97 percent according to officials there-is under "customary ownership," which means that boundaries have not been surveyed, title has not been registered, and the applicable law is custom. Intricate and detailed customs regulate the occupancy, use, and inheritance of land. However, customary law typically does not contemplate the sale of land

My research in Papua New Guinea was sponsored by the Institute of $\mathrm{Na}$ tional Affairs in Port Moresby and financed by a grant from the Asia Foundation. I would like to thank Leonard Joy, Richard Giddings, John and Jocelyn Millett, Tony Power, and Michael Trebilcock for help in organizing my trip. I am grateful to Jeremy Waldron and Wolfgang Fikentscher for useful discussions about theories of property and to Saul Levmore, Robert Scott, and Charles Goetz for discussions of relational contracting. My interest in this topic was partly inspired by Michael Trebilcock's (1984) "Communal Property Rights: The Papua New Guinea Experience." Useful comments were received from members of the Yale Workshop in Legal Theory, the University of Virginia Law Faculty Colloquium, the University of Pennsylvania's Law and Economics seminar, Peter Larmour, and the reviewers of this journal. Robert Mullen assisted with the manuscript's preparation.

LAW \& SOCIETY REVIEW, Volume 25, Number 4 (1991) 
to persons outside the kin group. Consequently, no individual or group has customary power to make sales to outsiders. PNG is one of the last places on earth that lacks markets in land, not because they have been suppressed as in communist countries but because they have not been invented.

The opening of villages to a larger world has created opportunities for profitable transactions in land on a wider scale. In addition, a shifting, mobile population requires continual reallocation of property to retain balance between land and people. If customary land is to be sold and leased, new powers must emerge. My research reveals three rival paths leading to new legal powers in PNG. One alternative is to allocate customary land to individuals in freehold, thus converting the legal regime from customary law to Australian common law. Another alternative is to reconstitute kin groups as collective enterprises, such as cooperatives, and vest ownership of land in them. As a third alternative, novel forms of market property that are more congenial to tradition are being invented by customary groups, often outside the framework of formal law. These novel forms of property are likely to evolve through the common law process, without legislative intervention.

Customary land law in PNG is adjudicated in special courts created for that purpose. This article recounts some of my observations of magistrates in the land courts and related officials, which took place from May through July of 1988, and uses modern economics to interpret these observations. I focus on the three alternative ways, mentioned above, to create the legal powers necessary for the emergence of a market in land. I find that the wholesale conversion of rural land to freehold disrupts the agricultural economy and dislocates the life of the countryside, and any attempt by central authorities systematically to impose cooperative forms on kin groups would also have dismal results. I conclude that conversion to freehold is sound only within the narrow compass of emerging towns and cities, and reconstituting kin groups as cooperatives could only succeed by local initiative in a few places. Reforming land law by the common law process seems more promising to me than transforming it by legislative fiat along capitalist or socialist lines.

Part I provides background material on Papua New Guinea essential to interpreting the details of my study. The reader already knowledgeable about PNG may proceed directly to Part II. Part II concerns the relationship between customary ownership and markets for land. I explain the need for markets and the gap in customary law. This section also describes failed attempts at wholesale conversion of customary ownership into freehold. Finally, Part III explains in detail why the common law process seems the most promising way to create market property. 


\section{BACKGROUND}

The Independent Nation of Papua New Guinea, which has a population of 3.5 million people, occupies the eastern half of a large island and numerous smaller islands located at the east end of the Indonesian archipelago, to the north of Australia. The highlands in the interior of the main island, which are temperate in climate, were believed by the outside world to be largely uninhabited until contact was made in the 1930 s, but it turned out that a majority of the nation's people live there. The coastal zones of the main island, which are tropical, are less densely populated, presumably because of endemic malaria. The third geographic region consists of all the smaller islands, with variable population density (see generally Papua New Guinea 1980).

There are about seven hundred languages in PNG, defined as mutually unintelligible speech, which is far more than in all of Europe. ${ }^{1}$ The proliferation of languages suggests the extent of historical isolation and cultural variation. The language of petty commerce is Pidgin, which combines German, English, and indigenous vocabulary with a rudimentary but serviceable grammar. The language of government, education, and international business is English.

PNG is associated in the minds of some people with cannibalism and technological backwardness. It is true that cannibalism was widespread and that while other societies created cities and high culture, the people of PNG continued living in small communities and relying on Stone Age technology. There is, however, another side to the story. The highlands of PNG are one of the oldest agricultural regions in the world, comparable in antiquity to Egypt, India, or China. The agricultural problem in the highlands is too much water, not too little, and archaeological studies have dated drainage channels cut in the Wahgi Valley at 9,000 years old. ${ }^{2}$ Throughout this long history people lived in small groups of kinsmen. Over thousands of years of agriculture, however, the highlands of PNG developed no permanent class of serfs, slaves, landless paupers, tenants, nobles, kings, or landlords. ${ }^{3}$ The people of PNG have historically enjoyed a large measure of liberty and equality. Nor did centuries of use by farmers degrade the environ-

1 This converitional figure (cited in Goldring 1978:7) was confirmed in private discussions with the Dutch linguist Wietze Baron.

2 For a survey of highlands archaeology, see Golson 1977:601-38, esp. 612-16.

3 Social stratification and political centralization is, according to Roy Wagner, a "nonsubject" in PNG because no evidence of its existence has ever been found. In conversation Professor Wagner told me that he asked Father Ross, who was one of the first whites to enter the highlands and who remained there for over thirty years, whether he had ever seen any evidence to contradict this common belief among scholars. His reply was negative. For an account of what political power traditionally meant in PNG, see Ongka 1979. 
ment, at least in comparison to the "cradles of civilization." The material standard of life, as measured by aboriginal wealth in the subsistence economy or wages in the money sector, is higher than in other countries that are more advanced technologically. ${ }^{5}$

In the highlands people lived in small communities for thousands of years without ever unifying under a single administration (see note 3). Nations and empires of the scale known in Europe and elsewhere did not arise. There appears to have been a pattern of shifting alliances, rather like Lebanon in the $1980 \mathrm{~s}$, in which hostile groups become allies long enough to prevent domination by a third party. Whenever a coalition threatened to dominate its neighbors, some of its members would be induced to defect to another coalition. The pattern seems to resemble what theorists call a game without a "core." 6 The maximum size of coalitions among kinship groups in the highlands remains far short of the coalition of the whole needed to secure peace.

A permanent peace, which required a government based on principles other than kinship, was imposed by the colonial powers. The northern coast of the main island was colonized by Germany, and the southern coast was colonized by Britain. The whole area was later united under Australian administration after World War I. The colonial powers assumed the role of the Hobbesian sovereign and imposed peace by harshly punishing its violation. Tribal fighting, which nearly ended under the Australian administration, has revived since independence was granted in 1975. Armed civilians, burned houses, and crop destruction can occasionally be observed by the traveler in the highlands today. In addition to tribal fighting, which enjoys clan sanction, criminal gangs have emerged that engage in such activities as armed robberies of trade stores or stopping buses to rob passengers and rape women. The gangs are apparently better armed than the police, and criminal justice ad-

4 The main effect of human occupation has been to diminish the scope of forest and increase the scope of grassland. See Sorenson and Kenmore 1974; Sorenson 1972, 1976; Lipuma 1988.

5 According to Goodman, Lepani, and Morawetz (1985:62, Table 3.7), average nonagricultural wages in selected developing countries in U.S. dollars per week are, reputedly, as follows: PNG, \$62.07; Honduras, \$35.93; El Salvador, \$29.14; Western Samoa, \$26.41; Nigeria, \$21.98; Philippines, \$10.50. Such data must, in my opinion, be treated with great skepticism, although I do believe that the material standard of life in PNG is higher than in the other countries as indicated.

For a discussion of the traditional agricultural sector see ibid., pp. $71 \mathrm{ff}$.

6 The core concept is developed in Telsor 1978:3. Cooter 1989a applies the core and other game-theoretic concepts to PNG. The two outstanding facts about these coalitions are their limited size and their shifting composition. Many factors would figure in a complete explanation of these features, including (i) inherent difficulties in communication and transportation due to the terrain, (ii) a Stone Age technology of warfare, (iii) limits to the possible extension of kinship, (iv) random shocks such as crop failures and disease, (v) the opportunity to acquire different technology and genes by shifting alliances, (vi) cultural and linguistic similarities and differences. 
ministration is not systematic enough to hold people in prison for very long. ${ }^{7}$

PNG is a true parliamentary democracy. When people talk politics, they do not look over their shoulders to see if a policeman is listening. The army is small and plays no role in politics. In elections to office, whether at the federal or provincial level, losers step down and yield office to winners. The old game of clan alliances, however, appears to have been projected onto the new game of parliamentary democracy, which also suffers from unstable, shifting coalitions.

Kinship groups in PNG are pervasive and variegated, reflecting the nation's cultural diversity. To illustrate, some highlanders distinguish the "small clan," which might consist of a couple of dozen people up to a hundred or more, from the tribe or "big clan," which might encompass several thousand people. Other peoples do not recognize large kinship structures, although they may perceive an affinity with those whose languages are similar to their own. The PNG census, true to its colonial origins, fails to record affiliation with customary groups, thus omitting the most vital demographic fact about PNG as viewed by its own citizens. There is, consequently, no systematic evidence on the size and form of customary groups in PNG as a whole. ${ }^{8}$

The traditional economy for most people in PNG was slashand-burn agriculture, supplemented by hunting, fishing, and keeping pigs. The basic pattern of life remains unchanged for most people, although virtually everyone now has some access to markets and many smallholders raise cash crops, especially coffee and cocoa. Statistics report modest but steady increases in smallholder production of cash crops, which respond to changing international prices and other incentives. ${ }^{9}$ Yields from smallholder cash crop-

7 In Wewak and again in Maprik, I was told that the local police have guns but no ammunition because the gangs robbed the police arsenal. An experienced kiap, Rick Giddings, told me that sometime during the course of a year the night watch does not show up or the day watch forgets to lock the cells before going home with the keys, or the repair crew is late fixing the fence, and so on. He reckons that people who remain in jail more than a year or two do so by choice. Capital punishment is unconstitutional. If the police arrest or harm a criminal, it is highly likely that the criminal's relatives will seek revenge on a policeman, which dampens police enthusiasm for stopping crime.

8 After consultation with East Sepik officials and a guess of the average number of clans per village and the number of villages in the province, I estimate that there were about four thousand clans in the province.

9 Agricultural production occurs in the subsistence sector and the market sector. It is impossible to estimate either with accuracy. Goodman et al. 1985:72 write: "Estimates [of subsistence production] range from a rate of growth a little greater than that of the population (whether 2.3 or 2.8 per cent p.a.) to an actual decline. ... O Official opinion in recent years has tended to the view that subsistence production is either stagnant or growing only slightly." In contrast, where food production for the market is concerned, "the impression of officials and others in Papua New Guinea who are familiar with the rural sector is that this activity has been sharply on the increase in recent years. It has hap- 
ping are not as high on average as plantation agriculture, although interpretation of this result is difficult because the later applies more capital to land of superior quality (see Appendix Table 2). Steel tools are used by smallholders, but tractors are rare, except on the few large plantations. Those who live near roads have access to motor vehicles, especially the ubiquitous buses and trucks that ferry passengers and cargo for hire (public motor vehicles or PMVs).

The diet is usually described as ample, although heavy in native carbohydrates (root crops and sago) and rice. Meat traditionally consists of pork supplemented by fish and small game, especially possum and bandicoot, and more recently by canned beef, canned mackerel, and frozen sheep's bellies or similar fatty cuts of imported meat. PNG, being inside the zone of marsupials and cut off from the mammal life of the Asian continent, lacks large native game like deer or buffalo. Every kind of animal is eaten (smoked fruit bat, leg of cassowary, etc.) and even the songbirds are wary. Like food, clothing is adequate and variegated, mixing local products (e.g., possum-skin hats, sarongs, leaves draped vertically from a belt called "ass grass") with cheap imports (blue jeans, rock-n-roll tee shirts, Bermuda shorts). In the Maprik area, the elderly may appear in public wearing nothing at all, whereas in the highlands people bundle up against the cold night air.

Because of the favorable ratio of land to people, nature provides many villages with clean water and waste disposal. Rudimentary medical services are available in towns. The Australian campaign against endemic malaria in the lowlands has faltered and the incidence of disease is increasing. The government tries to combat drunkenness by limiting the hours during which the many outdoor beer parlors can sell the one commonly available alcoholic beverage, a local beer. Chewing betel nut, which is addicting and unhealthy, and smoking native tobacco rolled in newspaper, persist in the face of government campaigns against them.

Houses, which tend to cluster together on hills or ridges for security, are still made of bush materials, although sheets of tin or plastic are also common. The road system, while not extensive, continues to expand, but many gaps remain that are created by swamps or mountains. There are few roads in the interior except for the "highland highway," which runs from Mount Hagen down to the coastal city of Lae; other paved roads do not extend far beyond towns. Large rivers like the Sepik are transportation arteries. Most boats are dugout canoes, often powered by outboard motors.

pened without any initiative or assistance on the part of Government" (ibid., p. 75).

Production in the export sector is more easily quantified (see Goldthorpe's figures in Appendix Table 1). Also see Goodman et al. 1985:chs. 4 \& 5 . For a quantitative study of cash cropping and additional references, see Johnson 1988. 
The terrain is so forbidding, however, that much travel is in small planes. There are several commercial carriers that fly to the grass landing strips in isolated villages and towns, and the two missionary air services take paying customers when space is available. Small planes must be wary of natural perils like fog (no airport in PNG can land planes solely on instruments) and pigs on the runway.

Plantation agriculture and international business, especially the extraction and export of natural resources, create a large percentage of the nation's money income, while employing a small percentage of its labor force. Four large gold mines operated until recently, when a rebellion by local inhabitants closed the largest mine. ${ }^{10}$ After independence in 1975, plantation agriculture declined and some large estates were broken up and returned to their customary owners, although efforts are currently under way to revitalize plantation agriculture. Rapid increases in population in recent years make people feel that land is scarce even in areas where it once seemed abundant. ${ }^{11}$ Feelings aside, land is too scarce in some regions such as around Maprik for traditional agricultural techniques to support everyone born on it.

The surplus population in the rural areas must relocate, usually near towns. There are only two cities in PNG-the capital and administrative center of Port Moresby and the industrial city of Lae-each of which has a couple of hundred thousand people. Next in rank come the provincial capitals like Weewak and Rabaul, which have government offices and some business. Finally, there are many small towns and villages. It is important to realize, however, that almost every native of the country in a position of authority, from the prime minister on down, was born and raised in a village or small town. There is not as yet a permanent class of city dwellers administering the country.

People in PNG generally perceive, and often lament, the loss of influence of clans and other traditional groups under the impact of markets, media, schools, and government ("the youth don't respect their elders"). Some people attribute a long list of social ills to this decline, such as increases in crime, alcoholism, and illegitimate children.

10 Bougainville Island is the site of PNG's oldest and richest gold mine. Reports in local PNG newspapers indicate that customary land owners and local inhabitants demanded compensation from the mine and many of them apparently wished to secede from PNG. Mounting disorders led to the closure of the mine more than two years ago and a military stand-off between rebel and government forces.

11 If the population growth rate of around 2.3 percent reported by the census persists, population will almost double every 25 years. To be precise, the current population of 3.5 million will increase to 6.1 million in 25 years, 10.9 million in 50 years, and 34 million in 100 years. Several kiaps I spoke to believe that the population is growing faster than the reported rates. 


\section{CUSTOMS, PROPERTY, AND PROFITS}

Part I provided texture and context for the specific analysis of property in Parts II and III. I begin with the question, Who owns the land? which involves the question, What is ownership? Once these questions are answered, I explain why existing ownership rights are inadequate to current needs, and I discuss how legislative remedies have failed.

\section{Who Owns the Land?}

Viewed from an airplane or truck, much of PNG appears to be vacant jungle or bush. An outsider like me might conclude that much land is unowned. That was apparently the perception of colonial governments who appropriated some land, declaring it to be "waste, vacant, and ownerless."12 This false impression is dispelled by discussions with local people. Every plot of land-even jungle, bush, and swamp-apparently has a name, a customary owner or owners, and an oral history, usually including its resident spirits. There are "no-man's lands" that are especially dangerous because ownership is actively contested. And there are lands that a clan reserves for hunting or gathering firewood by its members in common. But I did not encounter any unclaimed lands or lands where access is open to a wide public, as with open-access fisheries on the high seas. "Unowned land" in PNG is apparently the invader's description of conquest.

Land is divided into two categories by legal status: customary land, which constitutes over 97 percent of the country's land area, and alienated land. ${ }^{13}$ For customary land, boundaries have not been surveyed, title has not been registered, the applicable body of law is the customs of the region, and many of the powers associated with ownership are exercised by customary groups. Alienated land, which has been brought out from customary law by a process of title conversion, is either owned by governments or held in freehold by private persons. The amount of land owned by the state is now thought to be slightly less than 2 percent, which leaves about 1 percent to individual ownership. ${ }^{14}$ Most alienated land is located in cities, towns, or rural plantations.

For two months I asked "Who owns the land?" in villages and

12 Peter Larmour explained this fact to me.

13 James 1985:33 presents a table that shows 97.25 percent of land unalienated and 2.75 percent alienated but gives no primary data source. Officials repeatedly cited this figure to me, among them Norm Oliver of the Land Titles Commission. It is apparently derived from the fact that according to colonial statistics, 97 percent of the land was in customary ownership when independence was granted in 1975, and that figure has increased modestly as customary groups repossessed land given to others by the colonial administration. For a history of land administration in PNG, see Fingleton 1982, Crocombe and Hide 1971, and Larmour 1986.

14 Chris Turtle, Papua New Guinea's Department of Lands and Physical Planning, private communication to Robert Cooter, 25 Nov. 1988. 
towns, among educated people in jobs and traditional people living off the land, on the coast, the highlands, and the islands of PNG. Everyone recognizes that almost all the land is in customary ownership, but who are the customary owners? The candidates for ownership are individuals, families, and various customary groups often called by the generic term "clan." Coastal villagers and university professors often say that the land belongs to clans. Highland villagers and businessmen often say that it belongs to families or individuals. ${ }^{15}$

Customary groups include various kinds of bands, clans, lineages, moieties, and tribes. Modern anthropology has developed powerful tools for analyzing the principles different peoples follow for naming kin, tracing descent, and relating kinship to residence, work, mutual aid, and religious duties. ${ }^{16}$ These principles are complex and tangential to this article. For my purposes the contrast between individual and group ownership usually suffices, without specifying the exact nature of the group. I usually use the term "customary group" or "clan," which has an expansive meaning in ordinary speech in PNG, rather than its narrower anthropological meaning. ${ }^{17}$

Although the general question, Who owns the land? provokes disagreement, there is much agreement about concrete details of ownership. Everyone agrees that among most customary groups in PNG, the clan as a whole defends its land, inheritance follows

15 "Broadly these [types of land tenure in PNG] fall into two categoriesthose in which there are group titles (vested in district group, clan, or lineage) without specific rights vested in the individual, and those in which there is a mixture of group and individual titles." Hogbin and Lawrence 1967:xii.

Richard Scaglion's students at the University of PNG conducted twentyfour case studies of customary law in their home areas. Scaglion (1983) summarizes their conclusions about land law:

While the specifics of land law vary widely from culture to culture, there are certain similarities. In general, land is communally owned. In such cases, there is rarely total alienation of land; usufruct rights may be granted in virtual perpetuity as long as users hold to the original terms of agreement. Alienation of customary land should be discouraged, and long-term leases should be negotiated.

According to my own reading of the twenty-four cases, fourteen students explicitly stated that land belongs to the clan or lineage group rather than to individuals, three asserted that individual ownership is customary, and seven were uncertain or ambiguous on this point.

For an economic analysis of ownership see Trebilcock 1984; see also Trebilcock and Knetsch 1981 and Trebilcock (1983). Background reading includes James 1978, 1985; Sack 1974; and Papua New Guinea Task Force on Customary Land Issues 1983.

16 For an elegant reduction of kinship to their underlying mathematical structures, see Lounsbury 1964:351-93. For background on the history and development of the anthropology of kinship, see Harris 1968, esp. pp. 494-513.

17 Anthropologists often divide descent groups into lineages, whose members actually trace their descent from a common ancestor, and clans, whose members do not actually trace out descent but still regard themselves as descended from a common ancestor (possibly a mythical figure or animal). See Kottak 1987:ch. 8, pp. 147-73. 
rules that can be distinguished broadly into patrilineal or matrilineal, land can be given as compensation by one group to another, one group can invite another to live on its land, and a family's claim to a piece of land is strengthened by spilling blood on it, burying dead in it, planting permanent crops, or building a permanent house on it.

How can people agree about details of ownership and disagree about who owns the land? The paradox arises because people have different rights in mind when they answer the question, Who owns the land? Those people who think about the responsibility to defend the land say it belongs to the clan. ${ }^{18}$ So do those coastal people who think about individuals asking the clan's permission to put in a garden. But those people who think about a parcel of land that a particular family has used for a long time-planted a garden, built a house, put in permanent crops, buried the dead-will say the land belongs to the family or individual.

Neither answer is wrong. The difficulty lies, not in the answers, but in the question. ${ }^{19}$ Full ownership, as English speakers understand the term, is a bundle of rights over the land, such as the right to occupy, use, develop, bequeath, inherit, sell, give, transform, and exclude others. ${ }^{20}$ If all these rights belong to one person, the question Who owns the land? has a right answer. In some circumstances, however, no one possesses some of these rights. To illustrate, customary law may specify inheritance, in which case no one has the right to choose an heir. Or customary law may forbid anyone to sell some parcels of land. Or customary law may allow the sale of land among families within the clan but never contemplate sale to outsiders. All these possibilities and many more are to be found among various customary groups. If important ownership rights are not the prerogative of anyone, then no one fully "owns" the land.21

18 In Ipao of Okiyufa and Apele of Masilakaiyufa 1985, Magistrate Phillip Takori decided that land belonged to the clan as a whole because it has defended it.

19 In a classic book on ownership in PNG, Sack 1973:41 has written:

Although the traditional right to control land resembles in some ways the Western concept of ownership, the group does not own the land it controls in the traditional sense. Land within a group's sphere of control remains ownerless. Further, not only the non-ownable land but also the ownable objects on the land remain ownerless when the right of control is established. The right of control merely constitutes a claim that the members of the group are entitled to acquire the ownership of these objects and that outsiders are not entitled to do so, unless they have the group's permission.

Reading this, is it any wonder that most people are confused about ownership?

20 "To own property is to have exclusive control of something-to be able to use it as one wishes, to sell it, give it away, leave it idle, or destroy it." Grey 1980:69.

21 Writes Dickson 1986:3:

Despite the basic acceptance that it is interests in land that an owner holds, western administrators were accustomed to the main interests 
So far I have discussed gaps in powers relative to full ownership as understood by English speakers. Another source of confusion occurs when the rights of full ownership are unbundled and dispersed among different people or groups. Instead of unitary ownership, there is fragmented ownership. To illustrate, customary law may give a family the right to plant subsistence crops on a piece of land, but the family may need the clan's permission to plant cash crops. Or a family may have the right to plant cash crops on a parcel of land, but the family may have to ask others for permission to bury its dead there. If ownership rights are dispersed among different people, asking who owns the land is like asking which player is the football team.

Visitors to PNG persist in asking the wrong question because it has a right answer in Australia or the United States. In these countries, where most land is owned in freehold, owners enjoy broad rights, traditionally described as "full and absolute dominion" over the property. Legal constraints prevent owners from parceling out their rights and dispersing them in ways that would interfere with markets. ${ }^{22}$ These restrictions preserve unitary ownership and reduce the transaction costs of market exchange. Complex leasing arrangements and land use regulations sometimes undermine freehold as a system of unitary, absolute ownership, but even so the resulting pattern of rights does not correspond to the situation in PNG or provide guidance in understanding it.

Unitary, absolute ownership is possible among individuals whose mutual obligations are minimal. If a stranger asks to buy some of my land, I am free to respond as I please, including a simple "No!" If, however, I am part of a clan and my nephew wants to buy some land, the answer is not simple. What do I owe his father, who is my brother? How severe is his need, relative to mine? Will he help defend my land? Can my children live amiably alongside his children? These questions arise because ownership of customary land is an aspect of long-run relations that involve many reciprocal obligations. These obligations affect customary rights to land and become relevant to the equities of land disputes. Gluckman (1975:171-73) summarized this situation succinctly with respect to an African tribe:

in any particular piece of land being concentrated in an individual, who had exclusive rights. They could fit the concept of communal ownership of a physical piece of land to ownership in the western sense to land held in undivided shares, but the concept of communal land being a very complex bundle of different interests, some inheritable, some annual, some overlapping, some fully communal, some to occur in a future circumstance, and some even inter-communal, was beyond western tenure systems. In some areas too the position of chiefs and headmen was taken to be that of the feudal land owners of Europe, instead of being only trustees of all the varying interests of the community in land.

22 Examples are the right of partition and the rule against perpetuities. 
I have argued that Barotse property law defines not so much the rights of persons over things as the obligations owed between persons in respect of things. . . . Trials over ownership of land may become inquiries into how the kinsfolk concerned have dealt with one another through long periods ... whether the junior gave the senior fish from his catchers and money from his earnings . . . whether the senior had contributed ... to his juniors' payments of cattle for brides ... the settlement of disputes over ownership may turn on whether the parties have fulfilled all the duties of their station.

\section{Balancing Land and People}

Throughout history some customary groups in PNG have flourished while others have languished, like families everywhere. The continual ebb and flow in the fortunes of the groups living off the land requires continual adjustment of ownership rights in order to avoid imbalances between land and people. The most visible expression of imbalances between land and people is the numerous squatter camps found near PNG's two cities and many towns. Section 52 of PNG's constitution gives citizens the right to move within the country or to reside in any part of it. Giving people the right to move does not, however, guarantee them a place to stay. There are more and more people moving to towns and cities in PNG where they have no land. Most of these urban migrants are being accommodated by relatives who generously make a little room for them on someone else's land. Perhaps the original settler had an understanding with the owners to pay a modest rent for temporarily occupying the land, but the arrival of more relatives and friends soon resembles, not a rental agreement, but an invasion. ${ }^{23}$

To illustrate, I estimate that squatters outnumber customary owners in Weewak by approximately 13 to $1 .^{24}$ Moreover, the numerical superiority of squatters over owners in many towns and cities is continually growing. ${ }^{25}$ Rapid population growth and large

23 "Customary Land owners are unwilling to part with their land and feel threatened by the ever increasing pressure for urban development. At the same time customary land owners are fighting a constant battle to keep migrants from settling on their traditional lands." Walsh 1985:20. For additional research on squatters in PNG, see Norwood 1984, Walsh 1987, and Bayne 1980.

24 There were an estimated 23,400 people living in the Wewak urban area in 1987 , of whom 51.8 percent were living in settlements in 1980 (1980 census figures projected to 1987 at the annual urban population growth rate of 2.8 percent, supplied by Joe Jareka, statistician for East Sepik Provincial Government). If settlements have grown at least as fast as the other areas in the period 1980-87, the ratio must now exceed 52 percent. The settlements are located on customary land owned by five villages whose combined population was 933. Joe Jareka identified and supplied 1987 population data for the five villages that are customary owners of urban land in Wewak.

25 The census estimates population growth to be 2.3 percent for the nation as a whole and 2.8 percent for urban areas. A bootstrap inference is that migration shifts population to cities at a rate of at least 0.5 percent per year. 
numbers of uneducated people farming by traditional methods assure a continuing flow of poor migrants to towns and cities.

Numerical superiority gives squatters substantial powers to trespass and occupy land, shirk paying rents, or otherwise disregard the rights of customary owners. Customary owners are reluctant to use police or courts to enforce their rights for fear of retaliation. Indeed, the police and courts also fear that intervention in these disputes will bring retaliation against officials. The incentive for illegal occupation of land is strengthened by the disarray in property law. Even if the customary owners are willing to sell or lease the land, squatters cannot obtain secure, legally enforceable contracts, for reasons explained later. When contracts are concluded, they often fail to provide for essential contingencies. For example, a third party may appear claiming to be the true owner of the land and demanding additional rent, or the original settlers may insist that the lease permits them to invite additional relatives to move onto the land, or the owner may demand a much larger rent after the tenant improves the land. There is little point in striking deals that do not cover important contingencies and may not be enforceable. ${ }^{26}$

The most wasteful and inefficient relationship between owners and squatters occurs when the owners cannot induce squatters to pay rent, but the possibility of eviction is sufficient to prevent squatters from investing in improvements like permanent houses or cash crops. Under these circumstances, bilateral uncertainty stunts investment and improvement of land.

\section{Cash and Clarity}

Ownership of land responds to population change, mobility, and economic development. Land can be reallocated among kin by traditional means, specifically through marriage, gift, and inheritance, or the elders can reallocate land among families as the village moves through the cycle of slash-and-burn agriculture. Between customary groups on friendly terms, territory can be given

This suggests that the numerical superiority of settlers over owners would increase by at least 0.5 percent per year. (Numbers supplied by Joe Jareka based on the latest revision of census data.)

Several kiaps expressed the belief that population is growing faster than official statistics indicate. The Boundary Road Settlements in Lae apparently grew at over 6 percent per annum through the $1960 \mathrm{~s}$ and $1970 \mathrm{~s}$, and by 1980 the growth rate had reached 11.7 percent per annum. Similarly, the 1980 average annual growth rate in the Omili Settlement in Lae apparently exceeded 10 percent. Walsh 1985:25 \& 30-31, Tables $7 \& 8$. Walsh also summarizes (p. 25) others' estimates of squatter populations: "Rofe (1967) estimated the population in Bumbu (Buko) settlement at 400 in 1963, which according to Jackson (1976) had grown to over 3000 by 1974 . At the 1980 census the population of the Bumbu settlement stood at 4460 persons living in 847 self-help housing units."

26 "At the root of these problems [of squatters' access to land] lies the issue of title to land." Bayne 1980. 
or ceded for the sake of mutual advantage. ${ }^{27}$ Between enemy clans, however, the historical mechanism for balancing land and people was invasion and occupation. ${ }^{28}$ Contemporary squatters and hostile groups in the highlands continue to draw on the old principle that the strong possess the land, not just the new principle that owners must consent to occupation.

In addition to these imbalances between land and people, the expansion of a cash economy has created demands by individuals and families for firm property rights that would stand against the claims of larger customary groups. To illustrate, consider the impact of urbanization on a clan. People in kin groups in the countryside are too enmeshed in each others' affairs to have the freedom that goes with unitary, absolute ownership. ${ }^{29}$ However, these bonds may loosen among customary groups living at the edge of expanding towns or cities. In these circumstances, families and individuals want more freedom to make their best deal for land and thus profit from its rising value. Thus some individuals within a customary group may demand the devolution of its ownership rights upon families and individuals.

As another illustration, consider the farmers' needs for capital. PNG's cash crops are trees that require initial investment and a gestation period, so access to credit markets has proved important to financing investment in cash crops. The only security of sufficient value that many smallholders can offer is land. However, land cannot be offered as security unless it can be seized and sold by a creditor on the debtor's default.

Dispossessing customary owners who default on debts is probably impossible. In fact, I did not find one example of a customary land owner who was evicted because of a default on a mortgage. Land has a special quality in PNG. It is no exaggeration to say that a clan's land is sacred, since its dead have been buried in it from time immemorial. Laws permitting burials in sites designated as cemeteries and prohibiting burials elsewhere, which facilitate a market by secularizing the land, are absent in PNG. A creditor who attempts to take possession of, say, a leasehold from a defaulting debtor will encounter resistance. Little wonder that customary groups have little or no ability to offer land as security for loans.

27 A case finding the customary right to give land is Notofana and Kofika Clans 1984.

28 "Throughout New Guinea fighting . . . was probably an important, though usually indirect, means of adjusting population to land resources" (Crocombe and Hide 1971:296). "[A]cquisition by conquest can be said to have produced a rough measure of social justice in that the larger groups with greater numbers supplied their requirements for expansion by annexing the lands of less populous and less powerful neighbors" (Fingleton 1982:115). "Although the Chimbu did not set out to conquer land, conquest was in fact an important traditional means of redistributing land according to the laws of supply and demand" (Nilles 1974:135).

29 Gluckman (1965) argues this point generally about property. For a good example of an application of his theory see Wilmsen 1989:43-67. 
They have had to find other'ways to finance profitable agricultural investments, primarily the pooling of accumulated savings by relatives.

\section{Sale and Lease in Law and Practice}

The traditional means of reallocating land obviously needs to be supplemented, especially for transactions between strangers. Sales and leases are the obvious solution, but the response of Parliament has been confused and heavy handed. Section 81 of the Land Act prohibits sale, lease, or disposal of customary land except to nationals in accordance with customary law (Land Act Ch. No. 185). This section appears to allow land transactions only when the buyer is a citizen of PNG and the transaction accords with custom. Customary law often allows transactions within customary groups. However, most magistrates I interviewed believe that customary law does not allow sales to people outside the kin group. The land courts are unwilling to enforce "commercial sales."

In contrast, some magistrates have recognized leases of customary land for commercial purposes. "Customary land lease agreements" may be unwritten agreements or written documents. ${ }^{30}$ Disputes arising from them can be adjudicated in the land courts, at least in principle. However, the formalization of customary law by the land courts has not proceeded far enough to eliminate the uncertainties and risks attending these transactions. ${ }^{31}$ Doubt about their validity has been increased in some situations by legislation. ${ }^{32}$ The parties tend to rely on kin groups and other long-term relationships, not officials, to guarantee promises.

To appreciate customary leases, one must distinguish informal understandings, which create shared expectations that have uncertain legal status, from formal contracts, which create enforceable obligations. An understanding supplies a vague, uncertain, and flexible basis for coordination and cooperation. The parties rely on informal means of interpretation and enforcement, and they adjust the terms of the understanding in response to changing conditions. In the event of a dispute, the aim of the adjudicator is to restore a working relationship between the parties. In contrast, the parties

30 The kiaps in some areas showed me forms for customary land lease agreements. The kiaps would witness the signing of these forms and the making of payments prescribed in them.

31 "The principal rationale for a system of registration of interests in customary land in Papua New Guinea revolves around the need to reduce uncertainty and therefore risk associated with economic activities involving land." Papua New Guinea Task Force on Customary Land Issues 1983:8.

32 Customary land lease agreements were formerly witnessed by kiaps in East Sepik Province. Some kiaps told me that they now believe the passage of the East Sepik Land Registration Act, which requires vetting of customary land deals before a government committee, has made such agreements void. So now, while customary groups await the establishment and operation of such a government committee, customary land lease agreements must be abandoned or else proceed without being witnessed by an official. 
to a contract try to be explicit about their obligations and rights. Even if conditions change, a party to a contract usually has the legal right to resist changes in its terms. The aim in adjudicating contract disputes is to decide the rights of the parties.

People may prefer understandings rather than contracts for a variety of reasons. Contracts may be too costly to draft, too risky in terms of possible legal consequences, and the parties may be unable to specify the relevant contingencies that should control the terms. Understandings may be especially attractive to parties who are in long-run relationships. It is well known in game theory that repeated play can solve problems of opportunism that would be fatal in one-shot transactions, so commitment to a relationship can serve as a substitute for binding legal agreements. ${ }^{33}$ Much the same point is made in the anthropological literature on dispute resolution among people with continuing relationships (see, e.g., Nader and Starr 1973:125-37).

I encountered examples of customary leases that must be understandings, not contracts, by virtue of their form and interpretation. To illustrate, an immigrant to Weewak built a trade store on land leased from the customary owner for a hundred years at a rent of 50 kina (about US\$55) per year. The "contract" contained no contingencies. The lessee, who is a university graduate, told me that if the land increases in value, he will, naturally, increase the rent that he pays. In fact, he had already done so by virtue of paying the funeral expenses of the lessor's relative. A hundred-year lease at a fixed annual rent without contingencies only makes sense for people accustomed to land dealings within a clan, who see the document as establishing a long-run relationship on terms that adjust to changing circumstances. If this understanding were treated as a contract and its terms were strictly enforced, cooperation between the parties would be destroyed.

Migrants to towns often want to lease land from remote owners, without any personal relationships. Indeed, the relationship between squatters and customary owners in towns sometimes has no more life than the relationship between landlord and tenant in Los Angeles. In these circumstances, the parties need firm contracts, not understandings. Although the courts have provided no help in solving this problem, custom is vigorously at work extending informal land law.

To illustrate, Job Suat, Assistant Lecturer in Cartography at the Technical University in Lae, owned a house in Bumbu settlement (also known as Buko settlement), where he lived for five years with his fellow Sepiks. He later sold the materials constituting his house for 700 kina (\$770) in cash with the stipulation that they be removed within three days. With funds from the sale, he 1989a.

33 This argument is developed explicitly in the context of PNG in Cooter 
bought another house in the settlement and the ground under it from his brother-in-law. This house he currently rents for 50 kina (\$55) per month to a schoolteacher. The rental agreement was drawn up by a lawyer in Port Moresby. Although the sums of money involved in these transactions are substantial, it is unclear how courts would respond if disputes were brought. According to $\mathrm{Mr}$. Suat, no one in the settlement has any written title or similar document. The people who regard themselves as owners are in fact squatting on land technically owned by others. Even if these obstacles could be overcome in court, the legal basis for enforcing the contracts is doubtful. These facts do not prevent property rights from being respected and contracts from being enforced, largely because the camp consists almost entirely of Sepiks who have organized for their self-government. ${ }^{34}$

\section{Lease Lease-Back: Law as Socialist Fantasy}

In principle, a legal vehicle exists for commercial leases of customary land by non-kin that avoids the preceding doubts and uncertainties. Even though section 81 of the Land Act (Ch. No. 185) blocks transactions in customary land, it is partially undone by section 16, which permits government to purchase or lease land from customary owners. Government can be an intermediary in land transactions ("indirect dealings") that would be illegal if conducted purely between private persons ("direct dealings"). Most of the discussion about section 16 concerns leases, not sales, with government as intermediary. Commercial agreements for the lease of customary land are required in principle to follow a form called "lease lease-back." 35 First, the customary owners lease the land to the state. The Minister for Lands and Physical Planning must be "satisfied, after reasonable inquiry, that the land is not required or likely to be required by the owners or by persons on whom the land will or may devolve by custom."36 After this test is passed, the land is leased back to the commercial developer by the state.

Lease lease-back could, in principle, result in widespread leas-

34 Job Suat currently lives in university housing on the Unitech campus but plans to move back to the settlement in the near future where he feels more secure. Suat acknowledges that the camp is a "breeding ground for rascals," but they do not harm people within the camp. Its residents apparently feel secure within its borders, even without any police services. To illustrate the strength of property rights inside the camp, people are packed so tightly that they have no space for gardens, yet there is a large patch of land that remains vacant because its owner is one of the original settlers in the camp who wants the empty space.

35 As explained above, $\S 81$ of the Land Act Ch. No 185 prohibits sale, lease, or disposal of land except to nationals in accordance with customary law, but $\S 16$ permits government to purchase or lease land from customary owners.

36 Land Act Ch. No. 185, $\S 15 .(3)$. The other face of this paternalism is that government cannot acquire native land by compulsion except for a public purpose. See Haynes 1986:§ 2((ii), pp. 7-9. 
ing of customary land, but its use has been obstructed in fact by a backlog of applications that are stalled in the Department of Lands. The Task Force on Customary Land Issues proposed in its Report of March 1983 to break this backlog, estimated at the time to be between 8,000 and 10,000 applications, by allowing direct dealings in customary land under certain conditions. The basic proposal is to allow customary groups to lease lands that have passed through formal registration. This procedure in essence requires hearings to establish that the customary group wishes its lands to be registered and that other groups do not object to registration. The actual registration process is quite detailed, with many procedural safeguards spelled out in the Report.

In practice, owners of customary land find that selling or leasing to non-kin by formal means, which involves government as a third party to the transaction, is difficult or impossible. The remaining alternative is to bypass government and engage. in direct transactions. Direct dealings with commercial businesses and foreign investors are certainly illegal. There is much talk in PNG of direct dealings. I observed substantial black market or gray market activity in land, although documenting its extent seems impossible.

Lease lease-back is a plan for massive regulation of land transactions. An alternative that goes further toward socialism is ownership by the state. In the colonial era the government had to provide extensive services to Australian civil servants to induce them to accept employment in PNG, including the provision of housing. The government built many houses on its own land for civil servants to occupy. That tradition continued after independence and benefits were extended to a broad class of civil servants, both natives of PNG and Australians working on contract. In recent years, however, a financial crisis has led to curtailment of benefits and privatization of many government assets. Government houses are being sold on generous terms or given to their occupants. This fact creates additional pressures on the small market for urban land as civil servants who are relocated scramble to find places to live.

PNG has limited experience with agricultural cooperatives or rural socialism. The government maintains some farms and ranches in the countryside, primarily to demonstrate new crops and techniques, and it maintains research stations to seek cures for crop diseases and develop new varieties of plants. The export of cash crops is monopolized by a government agency, thus assuring that smallholders pay hefty excise taxes. National legislation provides a legal vehicle for reconstituting clans as "business groups," but the rural population has shown little interest in them. ${ }^{37}$

Much to its credit, government has not attempted the reorgan-

37 See the essays in Atsir 1987; p. 5 mentions some functioning business groups, but the legal machinery described seems very ponderous. 
ization of the rural population. It seems unlikely that customary groups would find it any easier to reorganize along the lines of cooperatives than as corporations. Mattei's (n.d.) study of Somalia and French-speaking Africa found that socialist models of rural land management typically failed, and his analysis is similar to my own. ${ }^{38}$ To appreciate the problem, consider a rough distinction of customary groups into organizations and networks. Clan organizations have a governance structure, such as a headman or council of elders, that actively participates in decisions about allocating resources. Governance extends to decisions about occupancy, use, and transfer. Perhaps the closest analogy in the British legal tradition to clan organization and ownership in PNG would be an informally organized religious congregation which owns real property, even though it lacks a corporate charter. ${ }^{39}$

In contrast, clan networks lack a governance structure for resource allocation, although people are bound together in long-run relationships for economic cooperation. Clan networks restrict the occupancy, use, and sale of land through reciprocal obligations, even though no organization enforces them. The closest analogy in our legal tradition would be community norms that guide behavior among neighbors as described, for example, in Ellickson's (1986, 1991) study of California ranchers.

My point is that clan organizations have little in common with corporations or cooperatives, and clan networks have little in common with freehold ownership. For this reason I suspect that cooperatives, corporations, and freehold have a limited place in the immediate future of PNG's countryside. Future developments are likely to involve the evolution of customary forms.

\section{Conversion: Law as Capitalist Fantasy}

The Australian administrators of PNG tended to assume that, as economic development proceeds, land ownership must inevitably come to resemble freehold. ${ }^{40}$ This approach inspired the Land

38 Mattei (n.d.) describes, first, the failure of the attempt of the colonial government to introduce a Torrens System of individual ownership and the further failure of the national government's attempt to bring socialism to the countryside. By "failure" he means that, in spite of legislation, officials, and police, the rural people persist in following customary law as it relates to the land. Mattei's conclusion in favor of the evolution of customary law for Somalia is much like my own conclusions for PNG.

39 U.S. cases in which courts must decide who owns church property usually involve disputes between the church denomination and a rebellious local congregation or between different factions in a splintered congregation. U.S. courts have tried to defer to church authorities as much as possible in these disputes, thus respecting the rules by which the churches govern themselves, but sometimes the courts cannot avoid importing secular rules to decide cases. For a discussion of issues with citations to U.S. cases, see Nowak, Rotunda, and Young 1986:§ 17.12, pp. 1089-94. I am grateful to David Martin for discussing these points with me.

40 This view exerts a continuing influence in PNG (Papua New Guinea National Planning Office 1984:7): 
(Tenure Conversion) Act, which provides a mechanism for converting land from customary ownership by clans to freehold ownership by individuals. ${ }^{41}$ The act creates the Land Titles Commission to supervise, review, and decide on applications for conversion. The boundaries of the land must be surveyed and all the affected parties with ownership claims must agree before converting (sec. 9 (1)). A lengthy decision procedure in several steps is designed to protect the interests of affected parties. ${ }^{42}$ Disagreements among affected parties must be settled by mediation. Once converted, government guarantees security of title under the Torrens system of land registration. ${ }^{43}$

Proponents apparently contemplate conversion under two circumstances. A clan may have surplus land that it would prefer to sell to others rather than retain for itself. The clan may request conversion in order to realize the best price for its surplus land, which jumps on conversion. Or kin relations may deteriorate so far that a clan's members want to end reciprocal obligations with respect to land. Once a clan ceases to be effective in economic life, its members may prefer for the land to be allocated to individuals in freehold.

The Commission receives a steady stream of applications for land conversion, although little land has been converted (much less than 3 percent). ${ }^{44}$ Once converted, the land can be sold or

\begin{abstract}
Customary land tenure is unsuitable for the economic development of Papua New Guinea. ... We therefore propose that the long term objective of the State must be to register all customary land presently held under customary tenure so that individual or group titles can be issued. This we believe will reduce the frequency of land disputes, will provide surety of title, feeling of permanency, and enable easier conveyancing of land without fear. It will enable owners to mortgage their properties in order to develop their land.

41 Land (Tenure Conversion) Act of 1964; Land (Tenure Conversion Amendment) Act of 1987.

42 The steps are (i) an application must be filed; (ii) notice must given with opportunity to protest; (iii) if anyone protests, there must be mediation; (iv) if mediation fails, the registration process does not go forward; if mediation succeeds, the Land Title Commission officer makes a decision whether or not to convert the property; (v) affected parties have ninety days to appeal de-
\end{abstract} cision.

43 Since 1975 the Land Titles Commission has received the following number of applications:

\begin{tabular}{|c|c|c|c|c|c|}
\hline Year & Applications & Year & Applications & Year & Applications \\
\hline 1975 & 96 & 1979 & 25 & 1983 & 57 \\
\hline 1976 & 136 & 1980 & 27 & 1984 & 113 \\
\hline 1977 & 19 & 1981 & 33 & 1986 & 144 \\
\hline 1978 & 46 & 1982 & 39 & 1987 & 166 \\
\hline
\end{tabular}

The numbers suggest a surge of pent-up demand that was satisfied followed by a rising trend.

44 Over 97 percent of the land is allegedly in customary ownership (see note 13). Much of the remaining 3 percent is owned by the national or provin- 
leased to PNG citizens, or it can be leased to foreigners after the owners obtain government approval. ${ }^{45}$ The government constraint on land conversion inflates its price and creates serious economic distortions around cities and towns. The market in land around towns will be increasingly difficult to contain within the current legal framework.

The British empire offers examples of allegedly successful land conversion programs, notably in Kenya (Bredmeyer 1974), ${ }^{46}$ but conversion is generally regarded in PNG as a political and economic failure. ${ }^{47}$ Much of the recent work of the Land Titles Commission has concerned, not conversion, but reversion. ${ }^{48}$ Land reverts to customary ownership when there is a successful challenge to the agreement by which it was originally converted. ${ }^{49}$ The com-

cial governments. Thus, the amount that is held in freehold and thus available for market exchange must be much less than 3 percent.

45 Customary land that has been converted to freehold and registered cannot be transferred or leased for more than twenty-five years without approval of the Land Board. See $\S 12$ of Land (Tenure Conversion) (Amendment) Act of 1987 that replaced $\S 26$ of the Land (Tenure Conversion) Act of 1963. In lease lease-back, the annual value of the lease is ordinarily set at 5 percent of the unimproved capital value of the land.

46 For comparisons between Kenya and Papua New Guinea, see Australian National University 1971.

47 These remarks about the political assessment of conversion are supported by some sober analysis (McKillop 1989):

Tenure conversion was introduced in $\mathbf{1 9 6 3}$ to provide for the transfer of customary land to individual freehold title. The underlying concept was to facilitate a smooth evolutionary changes from a communal system to one of individual "free enterprise" based on family farms where freedom from customary obligations to other clan members would provide incentive to invest in farm development and build up assets for future generations. However, covenants on the title restricting sale, leasing and mortgaging of land have served to make the security of LTC [Land Tenure Conversion] title unattractive to lending agencies. Nevertheless, some LTC blocks have obtained credit for coffee development (e.g. the $\mathbf{4 0}$ ha Gomena Kopi block at Goroka).

Experience of LTC in the Easter Highlands to 1978 was reviewed by Fingleton (1981). He examined 15 blocks in the province which had been tenure converted on a sporadic basis. He found that customary interests had not been terminated by LTC and the group interests of traditional social organisations had prevailed; the registered titles were not regarded as a marketable commodity; the conversions had been wasteful in their requirements for manpower and financial resources; they were the privileged preserve of an elite; and the conversions had little influence on the development of the land (ibid. 49-61). In half the cases, development had taken place prior to the conversion application. There are now "over 200" LTC blocks in the province.

For a report on the failure of earlier efforts to rationalize land titles, see Hide 1973.

48 The files of the Land Titles Commission, which I examined in Port Moresby, contain many examples of customary groups reasserting their claims to government land.

49 "It is submitted that all pre-annexation dispositions of the absolute interest in customary land to non natives were void for want of capacity of the traditional owners to transfer land to strangers and their community" (James 1978:90). Also see Roebuck, Srivastava, and Nonggarr 1984. 
mission and the courts are reluctant to construe agreements differently from the way they were understood by the people who made them. Indeed, some theories of contract law hold that the essence of a contract is the "meeting of the minds," which presupposes that the parties share an understanding of the contract's terms. ${ }^{50}$ An implication of these legal theories is that customary owners cannot convert land without fully appreciating its significance. Freehold ownership goes against custom and usage in PNG to such an extent that conversion inevitably creates misunderstandings and disputes. Now clans are asserting that past conversions were involuntary or fraudulent, and their success before the commission and the courts has left a cloud over many freehold titles. ${ }^{51}$ Converted land has been returned to customary owners in some cases and compensation has been paid in others. ${ }^{52}$ Many clans have a colorable claim whose assertion has the potential to bring a large gain, which may account for what observers perceive as an explosion of such claims in recent years.

The Land (Tenure Conversion) Act envisions the members of traditional groups bargaining together and reaching an agreement to transform their customary land rights into freehold. The motive for the bargain is the mutual gain that comes from greater clarity and security in property rights. The broad outline of this process resembles John Locke's theory that property arises from mutual advantage and agreement to protect natural rights better. ${ }^{53}$ There is, however, a fatal difference. The Lockean model of the social contract envisions people bargaining together who already possess natural rights similar to freehold. They start bargaining from a position of absolute, unitary ownership by individuals in natural law. Natural rights resembling freehold convey to owners the power to make binding agreements with respect to the land. Customary owners in PNG do not start from such a position when they attempt land tenure conversion. Conversion to an alien system of ownership like freehold is not contemplated in customary law, so customary law does not clearly delineate who, if anyone, has the power to make such a decision. It is unclear how to satisfy Locke's condition that property arise from a voluntary agreement that re-

50 The "meeting of the mind" approach received its purest expression in the "will theory" of contract. In America the theory was modified to stress the objective signs by which people indicate agreement. The signs are the conventional elements of offer, acceptance, and consideration. For a recent comparison of alternative theories of contract, including the will theory, see Barnett 1986. The American theory discussed above is explained in Eisenberg 1982.

51 Note that under the Torrens system, the cloud of uncertainty represents possible government liability rather than risk to the private owner in freehold.

52 For a recent decision that, if it survives a government court appeal, will vastly expand government liability, see Miriung 1987.

53 . Locke 1961. Various theories of property, including Locke's, are formalized and applied to PNG in Cooter 1989a. 
spects natural rights, because conversion to freehold is not a power defined in customary law. What constitutes respect for customary rights in the circumstances of land conversion is unclear and controversial. It seems in retrospect that conversion created more uncertainty about title than it dispelled. This is, in essence, why the program of land conversion has failed in PNG.

Locke's theory that markets in land come from consensus agreements to sustain natural rights can be counterposed to Marx's theory that chicanery, fraud, bribery, and intimidation are the methods by which capitalists obtain land from customary groups. ${ }^{54}$ The effects of the transfer, according to Marxist theory, are the dissolution of customary groups and the engorgement of entrepreneurs. The trend toward land reversion, rather than conversion, and the tenor of the public debate surrounding it, suggest that the Marxist model appeals to tribunals deciding land disputes and to the public in PNG. The appeal of this model, however, is limited by the scope of land conversion, which applies to relatively little land (less than 3 percent as explained above).

\section{LAND COURTS AND THE EVOLUTION OF PROPERTY}

I have explained the need to sell and lease land in PNG, and the failure of legislation to create the legal foundation for markets. Now I turn to PNG's unique court system for customary land and consider its ability to solve the problem.

\section{Land Disputes Settlement Act}

The legal foundation for applying custom to land disputes is an omnibus statute called the Land Disputes Settlement Act (Independent State of Papua New Guinea Ch. No. 45). It provides for the creation of a system of mediators and courts to resolve disputes involving land under customary ownership. The land courts are bound only by this act and custom. The act prescribes certain uniform procedures, although not in great detail. I will describe the practices I observed, which are consistent with the prescriptions of the act. Land disputes are first brought before a mediator or a panel of mediators, who are appointed in principle by the Provincial Land Disputes Committees, although appointment in practice is often arranged by officers in the Department of Provincial Affairs or the Department of Lands. Most mediators are employed on a case-by-case basis, but the same mediators are repeatedly appointed ("ad hoc appointment from a permanent list"). The mediators are typically elderly men, usually with little formal education, who command respect because of their experience and

54 This is the problem of "primitive accumulation" discussed in part 8 of Marx's first volume of Capital. The transition Marx actually discussed is from feudalism to capitalism, not from tribal society to capitalism. Marx's theories are discussed in the context of PNG in Cooter 1989a. 
knowledge of custom. If a settlement seems possible after hearing the two sides, mediators will propose one. If the proposal is accepted, the legal process may end at that point, or the settlement may be referred to the local magistrate for approval. If, on the other hand, the proposal is rejected, mediators cannot dictate a decision to the parties.

After unsuccessful mediation, the mediators may refer the dispute to the local land court for a decision. Lawyers are generally excluded from land courts on grounds that court should be inexpensive and nontechnical, so that traditional people of limited means will have access and its decisions will be intelligible to them. ${ }^{55}$ At trial, a magistrate presides, but he sits with two or more mediators, and decision is by majority vote. The land court hears disputes referred to it de nouveau, as if mediation had not occurred. An effort is made to appoint mediators to the local land court other than those who originally mediated the dispute. However, in government stations, the land court magistrate is often the same person who appointed the original mediators. In practice, the magistrate and mediators know a lot about the dispute before they hear the case, especially in government stations, as opposed to towns.

If one of the parties is dissatisfied with the decision of the local land court, an appeal can be lodged with the provincial land court. If the provincial land court hears the case, it will examine the written record from the local land court and possibly call additional witnesses. Another significant difference from earlier stages in the litigation process is that the party who appeals to the provincial land court must pay a fee, unless the presiding magistrate waives it.

Above the provincial land court is the "National Court," which is PNG's supreme court. Appeal from decisions of provincial land courts to the National Court is limited, and there are not many published cases. ${ }^{56}$ The National Court, which is a court of general jurisdiction rather than a land court, sees its role as overseeing the Land Disputes Settlement Act but not interpreting custom. ${ }^{57}$ The National Court ostensibly proceeds as if custom were facts decided by lower courts. The strongest basis for appeal is, consequently, the claim that the provincial court departed from its statutory mandate in deciding a case. ${ }^{58}$ In practice, however, the

55 The exception is the case in which one of the parties happens to be a lawyer, in which case the other party is permitted to be represented by a lawyer as well.

56 I examined all the published cases of the National Court for 1979 to 1985 , and I found only a handful on customary land. 1988.

57 E.g., see Ningalimbi No. 2 and Rahita No. 3 Clans v. Mamlimbi Clan

58 Thus, in Auguste Olei v. Provincial Land Court at Port Moresby et al. $1984 \mathrm{McDermott}, \mathrm{J}$., reviewed on purely procedural grounds a decision of provincial land court. In Re Fisherman's Island 1979, Wilson, J., had to decide 
distinction between overseeing the statute and interpreting custom is not very sharp, and the National Court has made substantive findings about the relative weight that different customary principles should receive in land disputes. ${ }^{59}$

The Land Disputes Settlement Act specifies that disputes over customary land should be resolved by applying the act and custom, and the act establishes procedures and institutions for achieving this end, but it remains silent on the substantive law of property. Nothing, for example, is said about the extent to which ownership vests in individuals or customary groups. The act thus invites the land courts to make custom into the common law of property for PNG. However, the land courts do not know exactly how to accept this invitation, as explained in the next section. ${ }^{60}$

The very existence of PNG's land courts represents a departure from customary dispute resolution. ${ }^{61}$ Social control within clans is accomplished mostly by informal means such as gossip and "tit-for-tat." For deeper disagreements, there are traditional mediators and judges, such as elders and bigmen. Unresolved disputes can lead to violence, especially disputes between clans in the highlands or ethnic groups in squatter camps. ${ }^{62}$ The change to the

whether adequate procedures were followed by government authorities in finding that land belonged to government, not to clans, in the Port Moresby area.

59 The landmark case is State $v$. Giddings 1981, in which Kearnes, Dep. C.J., decided that the principles used by the provincial land court to decide a dispute over ownership were not consistent with requirements of Land Disputes Settlement Act of 1975 or local custom. An equally important unpublished case, which was given to me by Justice Bredmeyer, is In the Matter of Application for Review of a Decision. . . of a District Land Court of the Land Known as Komonotoa between Ningalimbi No. 2 and Mahita No. 3 Clans 1987.

60 For a meditation on why the "underlying law" of PNG has not been developed, see Roebuck et al. 1984.

61 Paliwala 1982:191 writes:

Village courts were introduced in PNG in 1975 after the passing of the Village Courts Act 1973. Their establishment constitutes virtually the first granting by a government in PNG of formal judicial power to villagers. . . . The courts are "village courts" in the sense that the court officials are villagers selected by the village people themselves. They have a wide jurisdiction and, apart from the Village Courts Act, it is customary law and procedures which form the basis for the operation of the courts.

The Act, therefore, appears to reinforce customary law and practice. Yet, as is argued in this chapter, at the same time, the courts constitute a radical departure from pre-existing forms of dispute settlement, and social control generally, in rural society. The key changes are a greater involvement and control by the state and a degree of authoritarianism on the part of court officials. The result is relatively alienated dispute settlement with little scope for community involvement and party consensus. The transformation in rural dispute settlement corresponds to structural changes in rural society.

62 Ellickson 1986:677 found some similar methods of resolving disputes in a rural county in California. In general see Ellickson 1991. A major difference between PNG and Shasta County is the cost of exit-people could not traditionally survive outside of their clan in PNG.

There is a vast literature on dispute resolution in PNG. See O'Sullivan 
new and unfamiliar procedures of the land courts has been too abrupt for the courts to succeed in some regions of the country. To illustrate, the land courts in Enga Province created such controversy and the magistrates were in such danger from disgruntled disputants that the courts were suspended eight years ago and remain closed. ${ }^{63}$

In spite of difficulties, the land courts are quite active, as indicated by data that the Land Courts Secretariat collects from local officials on their annual activities. ${ }^{64}$ Between 1976 and 1987 there were, according to official statistics, an average of 63 disputes decided per year by the local land courts of PNG. The annual numbers varied from 31 to 111 , with no apparent trend. During the same period, provincial land courts, which hear appeals from local land courts, decided an average of 13 cases per year, varying from a high of 28 to a low of 2 . Although my own observations suggest that these data are not very accurate, there is ample evidence to conclude that cases are being decided often enough to drive the evolution of court-made property law. Land disputes requiring the refinement of property rights reach the courts with sufficient frequency to support the common law process.

\section{Principles of Customary Law}

The PNG constitution draws heavily on the Australian model, but Australia provides no guidance for legal recognition and treatment of traditional corporate bodies like clans. The British tradition in property law was developed for a society in which kin groups play an insignificant role in owning and using land, at least relative to PNG where the clan, lineage, or tribe stands between the individual and many of his dealings with others that concern land. Little wonder, then, that people in PNG perceive a gap in received property law. ${ }^{65}$

Perceiving the gap in received law has proved easier than fill-

1986 and Potter 1973. Some of the significant works are Carrad, Lea, and Talyaga 1982; Clifford, Morauta, and Stuart 1984; Colquhoun-Kerr and Lakau (1983); Gordon and Meggitt 1985; Hogbin 1978; Iamo 1980; Koch 1974; Meggett 1977; Nilles 1974; Paliwala 1982; Pospisil 1958; Roebuck et al. 1984; Sack 1973; Scaglion 1979, 1983 (Scaglion 1983 says: "Conflict management takes place in moots" (p. vi) in which there is no Stare Decisis but rather "guidelines" (p. vii)); Weisbrot, Paliwala, and Sawyerr 1982.

63 The lesson that Giddings (1980a, 1980b) draws from Enga is that mediation is far more successful than trials in the local land court, because mediation adheres more closely to customary law. Paliwala 1982:191 offers the view that village courts departs from customary law in ways that are beneficial to an emerging village elite. Also see Westermark 1986.

64 Appendix Table 3 gives the complete data set on the official number of cases decided in the local and provincial (appeals) land courts for each year of their existence, as supplied by the Lands Court Secretariat.

65 Narokobi 1986:215. This gap inspired the well-known line, "We must rebuild our society, not on the scattered good soil the tidal wave of colonization has deposited, but on the solid foundations of our ancestral land. 2, para." Constitutional Planning Committee 1973:ch. 98. 
ing it. Section s20(1) of the PNG constitution recognizes that received law is an imperfect expression of the Melanesian way of life and calls on Parliament to declare the underlying law. ${ }^{66}$ After sixteen years, Parliament shows no signs of answering the call. Politicians and intellectuals continue to say that law should express the Melanesian way of life, and they feel puzzled over delays and frustrated with obstacles. ${ }^{67}$

One reason for frustration is their failure to appreciate how law assimilates custom. It is a mistake to think that the underlying law can be declared by Parliament, or anyone else. The problem is not to declare what people know but to understand what they do. The underlying law consists of general principles that sustain particular practices and rules. ${ }^{68}$ The general principles must be discovered, not merely declared. Principles of customary law are discovered by abstracting the generalizations behind particular judgments, as has long been recognized (Llewellyn and Hoebel 1941). The land courts provide a unique forum for making particular judgments and justifying them by reference to general principles. Melanesian legal principles are to be discovered primarily while deciding cases in customary law, which must be done by courts, not Parliament.

Most land in PNG is divided by local people into named plots that are bounded by natural objects-rivers, trees, stones, bushes planted as markers, etc. Many disputes in local land court concern the precise boundaries of these plots and the identity of their customary owners. Resolution of these disputes in court creates the first written record of boundaries and titles. The local land courts are, in effect, engaged in sporadic registration of boundaries and titles at the initiation of private disputants. ${ }^{69}$ (The systematic registration of clan boundaries is currently under way only in East Sepik Province.) $)^{70}$

66 Goldring's The Constitution of Papua Newo Guinea (1978) is subtitled "A Study in Legal Nationalism." His discussion of the underlying law begins on p. 149.

67 E.g., Roebuck et al. (1984) is a meditation on why customary law has not been worked into the fabric of contract law. See especially the concluding chapter.

68 E.g., Pospisil's (1958) remarkable book Kapauku Papuans and Their Law abstracts the laws underlying the practices of one Papuan tribe. See especially "Offenses against Rights in Things," pp. 176-208, and "Contract," pp. 208-31. Also see Scaglion 1983.

69 For a case affirming a boundary between two clans, see Kefamo and Nagamiufa 1987. In my own experience, however, courts are not always able to locate records of land cases and, when found, the records are not always usable.

70 I visited the registration officers in the field. The legislation is called the East Sepik Province's Land Registration Act. There is a checkered history of attempted land registration in PNG, but this is the first example of the systematic registration of clan boundaries. Experience in related cultures suggests that registration can only proceed on the basis of boundaries among customary groups. See Crocombe 1974, which describes the failure of the registration 
Besides recording boundaries, the land courts must make explicit, authoritative statements of customary law. Custom contains some rules that could become formal law with little change other than writing them down. ${ }^{71}$ If that were the land courts' only task, their job would consist in cataloguing customary rules as reported to them by mediators and other experts on local customs. Custom does not, however, consist in a heterogeneous collection of particular rules without any underlying principles. Customary law is more often embedded in practice and usage whose implicit principles the courts must discover, extract, and refine. Finding general principles is the more challenging and difficult task for the land courts. The magistrates, judges, lawyers, and scholars form a community of intellectuals who must sift through cases and extract principles from details.

The magistrates in the land courts are civil servants who move from time to time and usually serve in districts away from their own homes. A magistrate who, say, comes from Madang may find himself presiding over a property court in Chimbu. The underlying law is similar enough in Chimbu and Madang that magistrates, aided by the mediators who are experts in local custom, can be moved from one place to the other and still do a reasonably good job in deciding disputes. If customary law were a heterogeneous collection of particular rules, a magistrate who was recently shifted from one place to another would be bewildered when faced with deciding his first land dispute. Thus the implicit premise under which magistrates are assigned to land courts in PNG is that general principles underlie the diversity of local custom.

I collected transcripts of cases from land courts and tried to identify underlying principles, some of which depart starkly from principles used in American courts (Cooter $1989 \mathrm{~b}$ ). ${ }^{72}$ To illustrate, the best known magistrate in the highlands decided that land surrounded on three sides by the relatives of one of the disputants belonged to that disputant because only he could defend it. On the basis of this determination, the owner was ordered to pay compensation for extinguishing the claims of the other party, who be-

scheme for the island of Niue as administered by New Zealand because the scheme registered only one level of rights, those of individual owners, whereas traditional operations allowed for multiple levels of overlapping rights.

71 E.g., "A man may not marry a woman whose clan name is the same as his father's." The only issue when applying this incest rule, which is customary among some peoples but not others, is the clan names of the wife and her husband's father. Bernard Narokobi, in his paper "History and Movement to Law Reform in Papua New Guinea," pp. 13-24, suggests that the following areas in customary law are clearly defined and could be easily worked into the formal law: marriage, adoption, obligations, land, crime/punishment, copyright, religion, ritual, and politics.

72 An example of an underlying principle is: "If the owner revokes permission for a tenant to occupy and use land, compensation must be paid to the tenant for the improvements that he made to it." 
longed to a rival clan. ${ }^{73}$ Another magistrate decided a case on the principle, "There is little point in a Land Court awarding a piece of land to a group if they will be unable to use it through intimidation or other pressure from rival groups."74 Similarly, another magistrate ordered the owner of land to compensate the evicted trespasser "to avoid further harassment by the latter and his men." "75 These decisions follow the Hobbesian principle that the allocation of property should respond to the natural power of the parties to threaten each other.

The fragmentation of ownership rights can create uncertainty about what was transferred in a particular transaction. For example, a person who sells a property may later assert in court that he continues to own some uses-rights. ${ }^{76}$ Fragmentation also leads to cases concerning the relative power of individuals and clans. ${ }^{77} \mathrm{~A}$ typical issue is whether a clan member who engaged in a transaction concerning its land was acting ultra vires. Not surprising, the courts typically void the sale of land by an individual who failed to obtain the clan's permission when required by customary law, but require restitution or compensation of the buyer. ${ }^{78}$ This outcome retains an incentive for the clan to discipline its members without allowing unscrupulous individuals to sell off clan lands. Such cases also demonstrate that customary law encompasses contracts and related forms of voluntary transfer.

Another kind of issue that arises is whether clan members must follow the clan's procedures in enforcing its rules. To illustrate, one member of a subclan attempted to evict a member of another subclan who had encroached on land belonging to the clan as a whole. The land court decided that the power of eviction belonged to the clan as a whole, but no individual acting on his own could exercise it. ${ }^{79}$

Some cases illustrate the way group ownership raises the transactions costs of development. To illustrate, two relatives shared the use of land for years that each claimed was his. One of the parties sold the land, or his share in it, to an aggressive third party who wanted to invest in the land's improvement and development. However, the court ruled that the land was under shared

73 Hogeteru et al. 1978. A similar principle is announced by Magistrate Giddings in Tobuka and Anglimka, Customary Groups 1986, and LivikoKarafa and Namori-Sibite 1977.

74 Mundua Imbo and Dambayagl Endemongo 1982.

75 Mundua Imbo and Dambayagl Endemongo Concerning the Land Gagl 1983.

76 See Negius Balanguan and Michael Varting 1986.

77 See Mundua Imbo and Dambayagl Endemongo 1985. Also see Enos Malakit and Jonah Tourai v. Peter Tobung 1987.

78 Ibid.

79 Dango Mondo of Bowaikane Subclan and Korugl Goi of Awakane Subclan 1987. 
ownership and both parties must agree to any development of it. ${ }^{80}$ In a similar case, a clan recovered land that one member sold to a buyer without the permission of the group as a whole. ${ }^{81}$ In such cases, the transaction costs of development decisions are increased by group control in the short run. However, other cases suggest that respecting the equities of a dispute by adhering to custom promotes cooperation and development in the long run, even when transaction costs are raised in the short run. ${ }^{82}$

Perhaps my most important general finding in studying the land courts is that custom lives and adapts to novel situations. This phenomenon is iliustrated by a change in custom recognized by the local land court in Rabaul. ${ }^{83}$ Before 1953. Tolai custom apparently permitted the leader of a clan to decide whether to sell its land. As population pressed on the land, and as cash cropping increased land values, the Tolai became alarmed that irresponsible leaders were disposing of clan land for their private profit. To solve this problem, the customary rule was changed and now clan land cannot be sold without agreement of all the affected members.

The reader may wonder how the custom was changed since there are no explicit rules for doing so. Changing custom is not too difficult when there is substantial support for the change from the community at large because bigmen in PNG, rather than being at the top of a hierarchical chain of command, derive their authority from the respect that they inspire and the prestige that they earn. Kinsmen do not persist in feeling bound by bad decisions of bigmen. Tolai bigmen lost their unilateral power to sell clan land as soon as their kinsmen stopped recognizing that power. The local land court later changed its decisions to conform with this change in customary law.

These examples suggest the shape of a common law of property for PNG. At the most abstract level, it would contain general principles that apply widely, perhaps universally, in the country. In addition, it would contain specific rules that apply to some groups, like the Tolai, but not to others. The application of the rules and principles to particular cases will always require local knowledge of the kind provided by mediators, elders, and other experts on local custom.

Many clans apparently exhibit tension between elders, who

80 Genaboru-Kibiso and Paul Lora Boiyango 1978.

81 Enos Malakit and Jonah Tourai v. Peter Tobung 1987.

82 To illustrate, two parties developed a joint cattle project on marginal riverine swampland over which village pigs formerly enjoyed free range. The land later increased in value because it proved suitable for a coffee plantation. Each of the two parties claimed it, but the magistrate held that they had an equal interest in it, so development would require cooperation between them. See Tobuka and Anglimka, Customary Groups 1986.

83 Enos Malakit and Jonah Tourai v. Peter Tobung, concerning the land called Vunateten 1987; also see Tobernat Tokuna and Ia Bore Maria, concerning the land called Rakakava of Tavuiliu 1982. 
hold traditional authority, and the youth, who are better educated. Combining continuity with innovation requires giving a voice to youth while retaining control by elders. One possible solution is to adopt more of a committee style of decisionmaking, as with sales of land among the Tolai. In committee, everyone is heard; the bigman does not decide on his own. Officials in East Sepik Province have introduced legislation to provide a legal framework that would ease this transition. ${ }^{84}$

The customary law of PNG is confronted with new pressures that are so powerful, and circumstances that are so novel, that customary law may create the legal basis for markets in land within a few decades, rather than going through the gradual process of evolution that took centuries in England. There are, however, significant obstacles to adaptation. The articulation of the rules and principles of customary law is the work of an intellectual community, which has not fully emerged for customary law in PNG. Land court decisions, which are ample in number to sustain the common law process, circulate by word of mouth. Magistrates in land courts seldom read each others' decisions and I know of no instances where one magistrate cites another's decision when deciding a case. Magistrates' reluctance, like that of other government officials, to exert themselves unnecessarily for others by researching cases might be overcome by lawyers in an adversary system, who have an incentive to scour precedent, but the land courts exclude lawyers. In addition to the usual sloth of officials, magistrates have an imperfect understanding of the common law process. Some magistrates explain their decisions by reference to particular facts alone, without connecting them to rules or principles. To hasten the process of making custom into the indigenous common law of PNG, magistrates need more training in common law methods and a modest increase in, or reallocation of, resources. ${ }^{85}$ Probably re-

84 The basic proposal is to allow clans to form incorporated land groups with a minimal constitution. In a communication to me, A. P. Power, who is both a clan leader and an official in East Sepik Province, wrote:

The fact is today that customary management is in dire need of improvement. The young men have a grasp of the problems but they don't have confidence in the elders who can be bamboozled into making decisions that are not in the long term interest of the clan. These discussions can be spurred by greed or even misguided respect for application for land, timber rights, etc. by rich and powerful people like National Ministers for example. Incorporation of Land Groups will give them a chance to develop decision making by Committee which will give an opportunity for the younger men. Just as customary law can be developed so also decision making systems can be improved.

85 Many magistrates have spent a year at the University of Papua New Guinea where they received training in law. Their training does not, however, touch on the common law process as it works in the land courts. In fact, their only training relevant to customary land law is reading the Land Disputes Settlement Act. One reason for this deficiency in education is the lack of teaching materials. To illustrate the problem, I examined all the books and journals on the shelves in the Rabaul courthouse library. I found eighteen Australian law journals consisting of $\mathbf{8 0 5}$ volumes, and sixteen English law journals consisting 
laxing the rule excluding lawyers from the land courts whenever both parties agree, as they might in important cases, would also facilitate the development of the common law.

\section{Court over Legislature}

Given the advantages of legislatures over courts in making law, ${ }^{86}$ national and provincial legislatures might be expected to take the lead in inventing forms of market property that are congenial to custom. Considerations of political economy in the context of PNG, however, suggest the opposite-that courts, not legislatures, will take the lead.

An important aim of constitutional design is to align the selfinterest of politicians and the public interest. One solution is to use electoral competition to create a kind of political marketplace. In spite of formidable obstacles in theory, this aim is central to democratic constitutions. ${ }^{87}$ An alternative aim is to make officials disinterested. By giving judges security of tenure at prescribed pay, and prohibiting them from hearing cases in which they have a direct material interest, judges may become relatively disinterested lawmakers. Severing the link between law and lawmakers' self-interest is the purpose of judicial independence. The implicit model of decisionmaking is that judges will do the right thing when it costs them no more than doing the wrong thing.

These two broad strategies for structuring the incentives of lawmakers-disinterest vs. aligned interests-each have characteristic advantages and disadvantages. The immediate issue, however, is not to weigh advantages and disadvantages in general but to consider the viability of these two strategies for PNG. I have argued that long-run relationships make kin groups relatively efficient at allocating resources and distributing wealth (Cooter 1989). This proposition presumably extends not just to land usage but to the relationship between a clan and its political representatives.

Politicians are expected to acquire power and wealth and to distribute services and money to constituents. To illustrate, fees are charged to students by state schools in PNG, even at the elementary level. Several politicians told me that when school fees fall due at the beginning of term, they expect to confront numer-

of 789 volumes. There were, in contrast, only three books immediately relevant to customary law in PNG and nine books on customary law in Africa. These figures may exaggerate the influence of English and Australian law in PNG's courts, since these journals are seldom read.

86 Legislators need not wait for a dispute to arise on a subject on which new law is required; they have broad powers to initiate inquiries and obtain expert opinion; they can bargain on behalf of constituents; and so on.

87 The conditions under which majority voting, directly or by representatives, will produce optimal laws are too restrictive to be realized in practice (see Arrow 1951). Black 1958 formulated symmetry conditions under which majority rule with single peaked preferences produces not just a stable equilibrium but an efficient equilibrium. 
ous relatives asking for their children's' tuition. Parliamentary politicians in contemporary PNG, like traditional bigmen, need wealth and power to provide their kinsmen with the services expected from office-holders. Thus the politician's self-interest and that of his clan are pretty well aligned.

I have also explained that clans were unable historically to secure peace by stabilizing large coalitions. This proposition apparently extends not just to traditional life but also to contemporary parliamentary politics. Just as custom lacks rules for efficient bargains with outsiders, so contemporary politics lacks rules for efficient bargains between clan leaders. Instead of consensus bargaining, parliamentary politics in PNG is characterized by weak parties, shifting alliances, and intrigue. The game of parliamentary politics as played in Papua New Guinea churns continually and apparently lacks a core (Cooter 1989a).

Under these conditions, political coalitions form to extract wealth from others. Opportunities for redistribution are magnified by PNG's many monopoly enterprises and quasi-public projects, which require government approval and assistance. Port Moresby abounds with stories of politicians obtaining wealth and privileges for themselves and their constituents at the expense of the country as a whole. ${ }^{88}$ The political culture does not align the public interest and the self-interest of politicians sufficiently to constrain rent seeking and other inefficiencies. The breakdown in the alignment of interests occurs not at the level of the clan and its representatives but at the higher level where the representatives of clans deal with each other.

Australia has bequeathed on PNG an independent judiciary with high standards of integrity that are apparently being maintained. Few of the magistrates in the land courts I encountered were serving in their home districts, so they did not have to decide cases that touched on their own clans. Furthermore, I heard no allegations of magistrates engaging in business transactions that would prejudice their decisionmaking. Allegations of bribery and corruption, which are common in the land courts, are typically directed not at magistrates but at mediators. Being experts in local custom, mediators often serve in their home districts, and they can become involved in cases that touch on the interests of their relatives. Furthermore, mediators do not have job security. ${ }^{89}$ These facts make them more vulnerable than magistrates. The relation-

88 During my visit, Sir Julius Chan, the second person to hold the office of Prime Minister and one of the countries leading politicians, was under investigation along with several other prominent members of Parliament for trading on mining stock of a company that was seeking valuable rights from the government. Sir Julius was exonerated by the investigating committee, although not in the minds of many of his countrymen.

89 That may be one reason why mediators seldom resist the judgment of magistrates in deciding cases, even though the decision is formally a majority vote in which magistrates and several mediators participate. 
ship between magistrates and mediators can be viewed as a successful compromise combining local knowledge and disinterestedness.

The strategy of disinterestedness in the courts seems to be succeeding better than the strategy of aligning interests in Parliament. This reason for preferring a common law of property to statutory law is based on incentives. There is also a reason based on information. As noted above, PNG displays bewildering cultural diversity. No parliamentary official understands the intricacies of land ownership among more than a few groups in the country. The land courts, in contrast, have access to far more local information. The courts possess the local knowledge needed to shape property law, which Parliament lacks. Under these circumstances, only a decentralized, common law of property can be just and efficient.

\section{Organization for Productivity}

I mentioned three alternative ways to organize ownership of land in order to promote its development. The approach favored by market conservatives is to convert customary land to freehold by legislative fiat and allocate it to families and individuals. This proposal, if adopted, would eliminate the kin group's role in allocation decisions over land. The second approach, derived from socialist principles, is to concentrate ownership rights in clans by legislative fiat. This proposal would reconstitute kin organizations as corporations or incorporated business groups, with explicit constitutions and designated officers. The third solution is to encourage customary law to evolve and produce its own answer to the question of ownership. Under this proposal, Parliament would remain neutral on the question of individual vs. clan ownership. Instead of a centralized decision, land courts would let custom take its course and enforce the changes that evolve.

I have offered some reasons why kin organizations and networks are efficient within the scope of their operation, and why custom can evolve and adapt to changing circumstances. If this account is correct, a framework for market transactions in land will evolve through changing customs. People will work out for themselves the forms of entrepreneurial organization best suited to their needs and preferences. The land courts should give people what they want, not tell them what to want. Legislative solutions, in contrast, might impede progress because centralized decisionmakers do not have the information or motivation to prescribe efficient rules for allocating land within PNG's multiplicity of kin groups. ${ }^{90}$

90 For the most insightful discussion of the interface between kin groups and modernization in PNG that I have read, see Pinda 1987; the author is chaplain of the Technical University at Lae. 


\section{CONCLUSION}

When law is weak or absent, people live in a so-called "state of nature." The state of nature is a life among kin. A life among kin is not a war of everyone against everyone, as characterized by Hobbes (1962:82), although the possibility of war with other kin groups persists. And a life among kin is not a condition of individual freedom as implicitly charactered by Locke (1974) and explicitly characterized by Nozick (1974), but rather a condition of mutual obligation. Theories of the origins of market property must take kinship seriously.

Elsewhere I have shown how the allocation of resources among kinsmen can be modeled as a repeated game, which creates norms of reciprocity that stabilize cooperation (Cooter 1989a). I hypothesize that the allocation of resources by custom is efficient and responsive to change within the scope of these enduring relationships. Customary owners do not waste resources, and they respond to new opportunities. Consequently, I hypothesize that custom includes a system of property law that is efficient within the kin groups to whom it applies.

The enjoyment of land in the past presupposed a contiguous group of relatives committed to protecting it. An outsider who obtained land surrounded by a hostile clan would be prevented from using it. Customary land transactions were typically limited to the members of a clan or its allies, and some groups had well-developed laws governing such transactions. ${ }^{91}$ Customary land transactions at the boundary of clan territory appear to be more like treaties between sovereign states than commercial sales. ${ }^{\mathbf{9 2}}$

The opening of villages to a larger world has created opportunities for profitable exchange with outsiders that customary law did not contemplate. To invent market property in land, a kin group must discover ways to transact with outsiders. The creation of market property extends the scope of exchange beyond kin groups to encompass outsiders. Indeed, market property can be regarded as a legal device to enable people to cooperate in one-shot games.

Customary groups do not encounter the land market for the first time with the necessary lines of authority already in place. In most clans in PNG, no one has the power in custom to sell land to outsiders. New legal powers must be created and allocated within

91 See Pospisil 1958, esp. sections cited in note 69.

92 I encountered an example in which one village invited another to occupy some of its land in the expectation of forming an alliance against a common enemy. I also encountered an example in which one clan sold some boundary land where security was problematic to another clan. Finally, I encountered many examples of land transactions between members of the same clan. I did not, however, find examples of sales of clan lands to outsiders in commercial transactions, except where such transactions were regarded as problematic departures from customary law. 
customary groups to create markets for land. The freehold solution is to give absolute, unitary ownership over land to individuals and end the customary group's role in resource allocation. Replacing customary land law with freehold substitutes markets for kin organization. If imposed by legislative fiat, the freehold solution will disrupt the customary economy by displacing its incentive system. This is the kernel of truth in the Marxist theory that market property begins with the destruction of preexisting collectivities.

The socialist solution is to reconstitute kin groups as collective enterprises and concentrate ownership in them. Socialists usually advocate paternalistic regulation of exchange by central authorities. This solution, however, disrupts customary law as much as the freehold solution, and also stifles exchange through bureaucratic controls.

Legislation that disrupts customs, whether in the name of capitalism or socialism, may create inefficiency where there is none. The history of the Land (Tenure Conversion) Act suggests that wholesale conversion of customary land to freehold ownership is likely to have such an effect, although selective conversion around towns may increase efficiency. The American analogy to wholesale conversion of customary land in PNG would be repealing the takings clause of the U.S. constitution and allowing Congress to redistribute land as it sees fit. This nightmare could only appeal to the politically innocent.

The alternative in PNG is for Parliament to remain silent and allow the customary law of property to evolve and modernize itself. ${ }^{93}$ The evolution of custom has reached a new stage through its application in formal courts, even though uncertainty surrounds both the property rights that the land courts will find and their ability to enforce their decisions. The land courts cannot invent custom, but by articulating it authoritatively, they can in time make custom into PNG's common law. Insofar as a market in customary land exists today, it functions largely without government approval or protection. The land courts can extend approval by enforcing transactions that accord with new, emerging customs, thus allowing custom, not government officials, to decide whether to augment the powers of individuals or clans.

This account of market property in PNG may provide insight into the history of other countries. For example, McCloskey's revisionist theory of the enclosure movement in England, which rejects the received belief that customs regulating the open field system were inefficient and unresponsive, shows some striking

93 The economic analysis of law has explored the question of whether, and in what conditions, the common law evolves toward efficiency. Increasing efficiency is an important aspect of modernization. For a summary and citations, see Cooter and Ulen 1988:ch. 10, pp. 477-505. 
resemblances to my observations of PNG. ${ }^{94}$ Besides tests of general theories of property, legal innovations in PNG provide lessons about policy that are valuable for those areas of the world in which substantial blocks of land are still owned by tribal people or influenced by customary law. For example, the government trustees who have presided over the theft and systematic mismanagement of Indian land in the United States and Canada, including the recent Alaskan Claims Settlement, ${ }^{95}$ could learn much from PNG. PNG has one of the few governments in the world that is staffed and controlled by tribal people. By contrast, Indians in the United States and Canada have no significant political influence. By looking to PNG, the shape of property law can be discerned as it faces business opportunities and responds in ways that serve the needs and objectives of tribal peoples.

94 McCloskey 1975a:73; 1975b:123; 1976; 1986. For a brief discussion of the significance of McCloskey's findings for law, see Kitch 1986.

95 A review of its provisions by the Native American Rights Fund (1987:1-3) concluded: "The effect on the Native land base and tribal existence could rival the disaster of the allotment era." A congressional amendment has somewhat ameliorated the effects of the original act. See Friends Committee on National Legislation 1988:5. 


\section{APPENDIX}

Appendix Table 1. Smallholder Production, Papua New Guinea, 1983

\begin{tabular}{lccr}
\hline & $\begin{array}{c}\text { \% of Total } \\
\text { Sectoral Production }\end{array}$ & $\begin{array}{c}\text { Trend 1979-83 } \\
\text { \% Change }\end{array}$ & $\begin{array}{c}\text { No. of } \\
\text { Smallholders }\end{array}$ \\
\hline Rubber & 14 & -12 & 7,976 \\
Oil palm & 48 & +11 & 4,500 \\
Coconut & 58 & +1 & 107,554 \\
Cocoa & 69 & +2 & 70,508 \\
Tea & negligible & n.a. & 279 \\
Coffee & 75 & +4 & 266,748 \\
\hline
\end{tabular}

SOURCE: Goldthorpe 1985:Table 4.4, based on Papua New Guinea Department of Primary Industry 1985b: Table 4.

Appendix Table 2. Papua New Guinea Estate and Smallholding Yields

\begin{tabular}{lcc}
\hline & \multicolumn{2}{c}{ Yield kg/ha } \\
\cline { 2 - 3 } Crop & Estate & Smallholding \\
\hline Rubber $^{\mathrm{a}}$ & $500-600$ (av.) & $200-600$ \\
Coconut $^{\mathrm{b}}$ & 900 & 500 \\
Cocoa $^{\mathrm{c}}$ & 400 & $\mathbf{3 3 0}$ \\
Coffee $^{\mathrm{d}}$ & 2,000 & $\mathbf{7 0 0 ^ { \circ }}$ \\
\hline
\end{tabular}

SOURCE: Goldthorpe 1985:Table 2.1, and sources given therein.

a Carrad 1981

backett and Williamson 1973

- Godyn 1974

d Department of Primary Industry 1985a

- Carrad 1985

Appendix Table 3. Land Court Cases Decided, Papua New Guinea, 1976-87

\begin{tabular}{rrrrrr}
\hline & Local & Provinical & & Local & Provinical \\
\hline 1976 & 71 & 11 & 1982 & 35 & 6 \\
1977 & 56 & 6 & 1983 & 80 & 14 \\
1978 & 45 & 28 & 1984 & 31 & 10 \\
1979 & 67 & 20 & 1985 & 71 & 8 \\
1980 & 111 & 19 & 1986 & 101 & 17 \\
1981 & 38 & 14 & 1987 & 46 & 2 \\
\hline
\end{tabular}

NOTE: I am grateful to Jocelyn Millett of the Institute of National Affairs in Port Moresby for copying this unpublished data for me at the Land Courts Secretariat. 


\section{REFERENCES}

ARROW, Kenneth J. (1951) Social Choice and Individual Values. New York: Wiley.

ATSIR, R. T. (ed.), Should There Be Another Approach to the Employment of the Business Groups Philosophy (Business Group Act. Cap. 144, and Land Group Act. Cap. 147) for the Productive Economic Engagement of Customary Land in PNG? Seminar Report 1/87, Department of Surveying and Land Studies, Papua New Guinea University of Technology, June.

AUSTRALIAN NATIONAL UNIVERSITY (1971) Land Tenure and Economic Development: Problems and Policies in Papua-New Guinea and Kenya. New Guinea Research Bulletin No. 40, Australian National University, March.

BARNETT, Randy (1986) "A Consent Theory of Contract," 86 Columbia Law Review 269.

BAYNE, Peter (1980) "The Law and Its Administration in Towns in Papua New Guinea," in Jackson et al. 1980 (which see).

BLACK, Duncan (1958) Theory of Committees and Elections. Cambridge: Cambridge University Press.

BREDMEYER, T. (1974) "The Kenyan Model," in Sack 1974 (which see).

CARRAD, Bruce, David LEA, and Kundapau TALYAGA (1982) "Blood Is the Argument," in Enga Yaaka Lasemana, Vol. 3: Enga: Foundations for Development. Arunidale, NSW: Department of Geography, University of New England.

CLIFFORD, William, Louise MORAUTA, and Barry STUART (1984) Law and Order in Papua New Guinea, Vol. 1, Report and Recommendations. INA/IASER Report. Port Moresby: Institute of National Affairs.

COLQUHOUN-KERR, Andrew, and A. L. LAKAU (1983) "Land Tenure and Land Dispute Settlement in Enga," 11 Melanesian Law Journal 59.

COOTER, Robert (1989a) "Inventing Property: Economic Theories of Market Property Applied to Papua New Guinea." Olin Foundation Working Paper 88-5, University of Virginia.

(1989b) Issues in Customary Land Law. Institute of National Affairs Discussion Paper No. 39, August 1989, Institute of National Affairs, Port Moresby.

COOTER, Robert, and Thomas ULEN (1988) "Efficiency of the Common Law Process," in R. Cooter and T. Ulen, Law and Economics. New York: Harper Collins.

CROCOMBE, Ron G. (1974) "The Niue Alternative Problem of Choice," in Sack 1974 (which see).

CROCOMBE, Ron, and Robin HIDE (1971) "New Guinea: Unity In Diversity," in $\mathbf{R}$. Crocombe (ed.), Land Tenure in the Pacific. Melbourne: Oxford University Press.

DICKSON, W. L. (1986) "An Introduction to Land Registration." Papua New Guinea University of Technology, Department of Surveying and Land Studies, May.

EISENBERG, Melvin A. (1982) "The Bargain Principle and Its Limits," 95 Harvard Law Review 741.

ELLICKSON, Robert (1986) "Of Coase and Cattle: Dispute Resolution among Neighbors in Shasta County," 38 Stanford Law Review 623.

(1991) Order without Law: How Neighbors Settle Disputes. Cambridge, MA: Harvard University Press.

FINGLETON, J. (1981) "Customary Land Registration as an Instrument of Social Change." Canberra: Australian National University, Department of Law.

- (1982) "Land Policy in Papua New Guinea," in Weisbrot et al. 1982 (which see).

FRIENDS COMMITTEE ON NATIONAL LEGISLATION (1988) "Alaska Native Claims Settlement Act Amendments: How the Debate Ended," Indian Report, I-29, Spring, 5.

GIDDINGS, Rick (1980a) “After 'Komanda': Implications for Land Dispute Settlement in Enga Province," Enga Integrated Rural Development Project, Dec. 
(1980b) "Land Dispute Settlement in Enga: Where to From Here?" Enga Integrated Rural Development Project, May.

GLUCKMAN, Max (1965) "The Importance of Obligation in Contract," in The Ideas in Barotse Jurisprudence. New Haven, CT: Yale University Press.

GOLDRING, John (1978) The Constitution of Papua New Guinea: A Study in Legal Nationalism. Sydney: Law Book Co.

GOLDTHORPE, C. C. (1985) "Plantation Agriculture in Papua New Guinea" I.N.A. Discussion Paper No. 19, Port Moresby.

GOLSON, Jack (1977) "No Room at the Top: Agricultural Intensification in the New Guinea Highlands," in J. Allen, J. Golson, and R. Jones (eds.), Sunda and Sahul: Prehistoric Studies in Southeast Asia, Melanesia and Australia. London: Academic Press.

GOODMAN, Raymond Charles LEPANI, and David MORAWETZ (1985) The Economy of Papua New Guinea: An Independent Review. Pacific Policy Papers. Canberra: Development Studies Centre, Australian National University.

GORDON, Robert J., and Mervyn J. MEGGITT (1985) Law and Order in the New Guinea Highlands: Encounters with Enga. Hanover: University of Vermont Press of New England.

GREY, Thomas C. (1980) "The Disintegration of Property," in R. Pennock and J. W. Chapman (eds.), Property (Nomos XXII). New York: New York University Press.

HARRIS, Marvin (1968) The Rise of Anthropological Theory. New York: Crowell.

HAYNES, C. E. P. (1986) "Compulsory Acquisition," in Land Law and Land Policy in Papua New Guinea: Text, Cases and Materials. Port Moresby: University of Papua New Guinea Printery, 1986).

HIDE, R. (1973) The Land Titles Commission in Chimbu: An Analysis of Colonial Land Law and Practice, 1933-68. New Guinea Research Bulletin No. 50, Australian National University. Canberra: Australian National Unviersity.

HOBBES, Thomas (1962) Leviathan, ed. M. Oakeshott. New York: Collier Books.

HOGBIN, Ian (1978) The Leaders and the Led: Social Control in Wogeo, New Guinea. Carlton: Melbourne University Press.

HOGBIN, Ian, and Peter LAWRENCE (1967) Studies in New Guinea Land Tenure. Sidney: Sydney University Press.

IAMO, Wari (1980) "Customary Dispute Settlement in Urban Areas," in Jackson et al. 1980 (which see).

JACKSON, Richard, with John ODONGO and Patrick BATHO (eds.), Urbanization and Its Problems in Papua New Guinea. Proceedings of the 1979 Waigani Seminar on Urbanization. Port Moresby: University of Papua New Guinea.

JAMES, R. W. (1983) "Introduction to the Laws Governing the Ownership of Land in Papua New Guinea," in "Land Tenure in Papua New Guinea." Port Moresby.

(1985) "Land Law and Policy in Papua New Guinea." Monograph No. 5, 1985. Port Moresby: Papua New Guinea Law Reform Commission.

(1985) Land Law and Policy in Papua New Guinea. Port Moresby: Papua New Guinea Law Reform Commission.

JOHNSON, Patricia Lyons (1988) "Women and Development: A Highland New Guinea Example," 16 Human Ecology 105.

KITCH, Edmund (1986) "Law and the Economic Order," in L. Lipson and S. Wheeler (eds.), Law and the Social Sciences. New York: Russell Sage Foundation.

KOCH, Klaus-Friedrich (1974) War and Peace in Jalerno-The Management of Conflict in Highland New Guinea. Cambridge, MA: Harvard University Press.

KOTTAK, Conrad Phillip (1987) "Kinship and Descent," in Cultural Anthropology. 4th ed. New York: Random House.

LARMOUR, Peter (1986) "Customary Land Registration in Papua New Guinea, Solomon Islands and Vanuatu." Land Studies Centre Occasional Paper 86/4, University of Papua New Guinea. 
LIPUMA, Edward (1988) The Gift of Kinship: Structure and Practice in Marine Social Organization. New York: Cambridge University Press.

LLEWELLYN, K. N., and E. Adamson HOEBEL (1941) The Cheyenne Way: Conflict and Case Law in Primimtive Jurisprudence. Norman: University of Oklahoma Press.

LOCKE, John (1961) "Of Property," ch. 5 of The Second Treatise of Civil Government, in T. I. Cook (ed.), Two Treatises of Government. New York: Hafner.

LOUNSBURY, Floyd G. (1964) "A Formal Account of the Crow- and OmahaType Kinship Terminologies," in W. H. Goodenough (ed.), Explorations in Cultural Anthropology. New York: McGraw-Hill.

MATTEI, Hugo (n.d.) "Socialist and Non Socialist Approaches to Land Law in Africa: Continuity and Change in Somalia and Elsewhere." Universita di Trento.

McCLOSKEY, D. N. (1975a) "The Economics of Enclosure," in Parker and Jones 1975 (which see).

(1975b) "The Persistence of English Common Fields," in Parker and Jones 1975 (which see).

(1976) "English Open Fields as Behavior towards Risk," in P. Uselding (ed.), 1 Research in Economic History: An Annual Compilation.

(1986) "The Open Fields of England: Rent, Risk, and the Rate of Interest, 1300-1815." Presented to American Economic Association meetings, New Orleans, Dec.

McKIILOP, R. (1989) "Land Mobilisation in the Highlands," in P. Larmour (ed.), Customary Land Tenure: Registration and Decentralisation in Papua New Guinea. Monograph 20, Papua New Guinea Institute of Applied Social and Economic Research. Port Moresby: the Institute.

MEGGETT, M. J. (1977) Blood Is the Argument: Warfare among Mae Enga Tribesmen of Papua New Guinea. Palo Alto, CA.: Mayfield Publishing Co.

MIRIUNG, Theodore (1987) "Bwagoia Township," Land Title Commission Application No. 1987/73 (13 July 1987).

NADER, Laura, and June STARR (1973) "Is Equity Universal?" in R. A. Newman (ed.), Equity in the World's Legal Systems: A Comparative Study. Brussels: Establissements Emile Bruylant.

NAROKOBI, Bernard (1986) "In Search of a Melanesian Jurisprudence," in P. Sack and E. Minchin (eds.), Legal Pluralism: Proceedings of the Canberra Law Workshop VII. Canberra: Law Department, Australian National University.

NATIVE AMERICAN RIGHTS FUND (1987) "Highlights of Indian Legislation in the 99th Congress: 1991 Legislation," 12 NARF Legal Review 1.

NILLES, John (1974) "Law Enforcement or Land Reforms," in Sack 1974 (which see).

NORWOOD, Hugh (1984) Port Moresby: Urban Villages and Squatter AreasAn Analysis of the Urban Villages and Squatter Areas of the City of Port Moresby in Papua New Guinea. [Port Moresby?]: University of PNG Press.

NOWAK, John, Ronald ROTUNDA, and J. Nelson YOUNG, (1986) "State Involvement in Ecclesiastical Disputes," in Constitutional Law. 3d ed. (St. Paul, MN: West.

NOZICK, Robert (1974) Anarchy, State, and Utopia. New York: Basic Books.

ONGKA (1979) Ongka: A Self-Account by a New Guinea Big-Man, trans. A. Strathern. New York: St. Martin's Press.

o'SULLIVAN, C. (1986) Tradition and Law in Papua New Guinea: An Annotated and Selected Bibliography. Canberra: Australian National University.

PALIWALA, Abdul (1982) "Law and Order in the Village: The Village Courts," in Weisbrot et al. (which see).

PAPUA NEW GUINEA (1973) "Constitutional Planning Committee, Final Report." Ch 2, para. 98.

- (1985) Department of Primary Industry 1985b, Table 4 (1980) Papua New Guinea Handbook.

PAPUA NEW GUINEA NATIONAL PLANNING OFFICE (1984) "Medium Term Development Strategy: Land Policy." Waigani, PNG: National Planning Office. 
PAPUA NEW GUINEA TASK FORCE ON CUSTOMARY LAND ISSUES (1983) Report (Presented to Minister for Lands, 1983), March.

PARKER, William N., and Eric L. JONES (eds.) (1975) European Peasants and Their Markets: Essays in Agrarian Economic History. Princeton, NJ: Princeton University Press.

PINDA, Fr. Gabriel Pinda, "The Melanesian Mentality and General Attitudes Towards Government Goods and Services in the Rural Communities," in R. T: Atsir (ed.), Should There Be Another Approach to the Employment of the Business Groups Philosophy (Business Group Act. Ca. 144, and Land Group Act. Cap. 147) for the Productive Economic Engagement of Customary land in PNG? Seminar Report 1/87, Department of Surveying and Land Studies, Papua New Guinea University of Technology, June.

POTTER, Michelle (1973) Traditional Law in Papua New Guinea: An Annotated and Selected Bibliography. Canberra: Australian National University.

POSPISIL, Leopold (1958) Kapauku Papuans and Their Law. New Haven, CT: Yale University Press.

ROEBUCK, Derek, Dhirenabra K. SRIVASTAVA, and John NONGGARR (1984) The Context of Contract in Papua New Guinea. Waigani: University of PNG Press.

SACK, Peter G. (1973) Land between Two Laws: Early European Land Acquisitions. Canberra: Australian National University.

- (ed.) (1974) Problem of Choice: Land in Papua New Guinea's Future. Canberra: Australian National University Press.

SCAGLION, Richard (1979) "Formal and Informal Operations of a Village Court in Maprik," 7(1 \& 2) Melanesian Law Journal 116.

- (ed.) (1983) Customary Law in Papua New Guinea: A Melanesian View. Law Reform Commission of Papua New Guinea, Monograph No. 2. Port Moresby: Law Reform Commission of Papua New Guinea.

SORENSON, E. Richard (1972) "Socio-ecological Change among the Fore of New Guinea," 13 Current Anthropology 349.

- (1976) The Edge of the Forest: Land Childhood and Change in a New Guinea Protoagricultural Society. Washington, DC: Smithsonian Institution Press.

SORENSON, Richard, and Peter KENMORE (1974) "Proto-agricultural Movement in the Eastern Highland of New Guinea," 15 Current Anthropology 67.

TELSOR, Lester (1978) Economic Theory and the Core. Chicago: University of Chicago Press.

TREBILCOCK, Michael (1983) "Customary Land Law Reform in Papua New Guinea: Law, Economics and Property Rights in a Traditional Culture," 39 Adelaide Law Review 191.

- (1984) "Communal Property Rights: The Papua New Guinea Experience," 34 University of Toronto Law Journal 377.

TREBILCOCK, Michael, and Jack L. KNETSCH (1981) "Land and Economic Development in Papua New Guinea," 9 Melanesian Law Journal 102.

WALSH, B. J. (1985) "The Demography of Squatter Settlements in Lae, Papua New Guinea." University of Technology, Department of Surveying and Land Studies, Nov.

WALSH, Crosbie (1987) Migration and Urbanization in Papua New Guinea: The 1980 Census. National Census, Research Monograph No. 5. Port Moresby: National Statistical Office, Feb.

WEISBROT, David, Abdul PALIWALA, and Akilagpa SAWYERR (eds.) (1982) Law and Social Change in Papua New Guinea. London: Butterworths

WESTERMARK, George (1986) “Court Is an Arrow: Legal Pluralism in Papua New Guinea," 25 Ethnology 131.

_- (Forthcoming) "Controlling Custom: Ideology and Pluralism in the Papua New Guinea Village Courts," 15 Legal Studies Forum.

WILMSEN, Edwin N. (1989) "Those Who Have Each Other: San Relations to Land," in E. N. Wilmsen (ed.), We Are Here: Politics of Aboriginal Land Tenure. Berkeley: University of California Press. 


\section{STATUTES CITED}

East Sepik Province Land Registration Act.

Land Act, Independent State of Papua New Guinea, Chapter No. 185.

Land Disputes Settlement Act, Independent State of Papua New Guinea, Chapter No. 45.

Land (Tenure Conversion) Act of 1963, Independent State of Papua New Guinea.

Land (Tenure Conversion) Act of 1964, Independent State of Papua New Guinea.

Land (Tenure Conversion Amendment) Act of 1987, Independent State of Papua New Guinea Chapter No. 45.

\section{CASES CITED}

Published Cases

Auguste Olei v. Provincial Land Court at Port Moresby, 1984 P.N.G.L.R.

In the Matter of Application for Review of a Decision ... of a District Land Court of the Land Known as Komonotoa between Ningalimbi No. 2 and Mahita No. 3 Clans, O.S. No. 24, 1987.

Re Fisherman's Island, 1979 P.N.G.L.R.

State v. Giddings, 1981 P.N.G.L.R.

UNPUBlished CASEs (Cases Listed Here Are Printed in Cooter $1989 \mathrm{~b}$; page numbers in brackets refer to that volume)

Dango Mondo of Bowaikane Subclan and Korugl Goi of Awa kane Subclan, Kundiawa District Land Court, 24 Nov. 1987, R. J. Giddings presiding. [Pp. 58-59]

Enos Malakit and Jonah Tourai v. Peter Tobung Concerning the Land called Vunateten, Local Land Court at Rabaul, 27 July 1987. [Pp. 80-81]

Genaboru-Kibiso and Paul Lora Boiyango, Local Land Court near Lindima Village, 20 Dec. 1978, R. J. Giddings presiding. [Pp. 63-67]

Hogeteru et al., Local Land Court at Kami, 19 Jan. 1978, R. J. Giddings, magistrate. [Pp. 70-72]

Ipao of Okiyufa and Apele of Masilakaiyufa, Local Land Court at Goroka, 28 Feb. 1985. [Pp. 92-93]

Kefamo and Nagamiufa, Local Land Court at Goroka, 18 Dec. 1987, Gesling presiding. [Pp. 94-96]

Liviko-Karafa and Namori-Sibite, Local Land Court at Kapakamari, 12 Jan. 1977. [Pp. 90-91]

Mundua Imbo and Dambayagl Endemongo, District Land Court at Kundiawa, 15 Feb. 1982, G. C. Lapthorne presiding. [Pp. 67-69]

Mundua Imbo and Dambayagl Endemongo, Local Land Court at Goroka, 19 March 1985, magistrate Phillip Takori. [Pp. 83-85]

Mundua Imbo and Dambayagl Endemongo Concerning the Land Gagl, Local Land Court at Kerowagi, 17 June 1983, S. Antonio presiding. [Pp. 83-84]

Negius Balanguan and Michael Varting, Local Land Court at Rabaul, 5 Aug. 1986, M.R. Golu presiding. [Pp. 61-63]

Ningalimbi No. 2 and Mahita No. 3 Clans v. Mamlimbi Clan, National Court of Justice, Wewak, 24 \& 25 Feb. 1988, T. Bredmeyer presiding. [Pp. 96-99]

Notofana and Kofika Clans, Local Land Court at Goroka, 26 Nov. 1984, Phillip Takori presiding. [Pp. 81-82]

Tobernat Tokuna and Ia Bore Maria Concerning the Land Called Rakakava of Tavuiliu, Local Land Court at Rabaul, 1982. [Pp. 80-81]

Tobuka and Anglimka, Customary Groups, Provincial Land Court at Minj, 12 June 1986. [Pp. 86-90] 
HeinOnline -- 25 Law \& Soc'y Rev. 8021991 